\title{
With Age Comes Maturity: Biochemical and Structural Transformation of a Human Centriole in the Making
}

\author{
Catherine Sullenberger *, Alejandra Vasquez-Limeta $₫$, Dong Kong ${ }^{\circledR}$ and Jadranka Loncarek * \\ Laboratory of Protein Dynamics and Signaling, NIH/NCI/CCR, Frederick, MD 21702, USA; \\ alejandra.vasquezlimeta@nih.gov (A.V.-L.); dong.kong@nih.gov (D.K.) \\ * Correspondence: catherine.sullenberger@nih.gov (C.S.); jadranka.loncarek@nih.gov (J.L.)
}

Received: 12 May 2020; Accepted: 4 June 2020; Published: 9 June 2020

\begin{abstract}
Centrioles are microtubule-based cellular structures present in most human cells that build centrosomes and cilia. Proliferating cells have only two centrosomes and this number is stringently maintained through the temporally and spatially controlled processes of centriole assembly and segregation. The assembly of new centrioles begins in early $S$ phase and ends in the third G1 phase from their initiation. This lengthy process of centriole assembly from their initiation to their maturation is characterized by numerous structural and still poorly understood biochemical changes, which occur in synchrony with the progression of cells through three consecutive cell cycles. As a result, proliferating cells contain three structurally, biochemically, and functionally distinct types of centrioles: procentrioles, daughter centrioles, and mother centrioles. This age difference is critical for proper centrosome and cilia function. Here we discuss the centriole assembly process as it occurs in somatic cycling human cells with a focus on the structural, biochemical, and functional characteristics of centrioles of different ages.
\end{abstract}

Keywords: centrosome; centriole duplication; centriole elongation; centriole maturation

\section{Introduction}

The centrosome is a major microtubule (MT)-nucleating center of vertebrate cells and functions in controlling cell and tissue architecture, cell signaling, cell proliferation, and cell motility [1-6]. Each of the two centrosomes present in a cell is comprised of a core component, a centriole, which is a MT-based cylindrical structure, and a surrounding proteinaceous matrix called pericentriolar material (PCM) that is organized by the centriole (Figure 1A). During cell division, two centrosomes organize the two poles of the mitotic spindle, a transient MT-based structure that mediates chromosome segregation (Figure 1B). Because of their essential role in segregation of genetic material to two sister cells during mitosis, it is vital that cycling cells contain exactly two centrosomes. In quiescent cells, the older of the two centrioles can convert into a basal body and assemble a primary cilium on the cell surface (Figure 1C), which is an antenna-like organelle that senses and transmits extracellular signals, linking them with intracellular signaling pathways [7-10]. Numerical or structural aberrations of centrioles can initiate tumorigenesis and are present in most cancers. Additionally, mutations in a large set of centrosome-associated proteins are linked to a group of hereditary diseases commonly known as ciliopathies (reviewed in $[5,11,12]$ ).

Centrosomes are highly ordered organelles with a complex assembly process. In this review, we illustrate major steps of centriole and centrosome assembly as they occur in cycling human cells, with emphasis on the gradual metamorphosis of a centriole from a small function-less procentriole to a fully mature centriole capable of organizing a functional centrosome and a cilium. Throughout 
the article, we mostly refer to findings pertaining to human centrioles. However, due to evolutionary conservation of centriole structure and its assembly processes [13-17], we sometimes refer to the findings obtained from other organisms. We could not reference all publications that explore centriole assembly and structure and we apologize to those whose work will not be explicitly cited. Additionally, this article does not discuss many interesting aspects of centrosome biology. Thus, we direct the readership toward other publications centering on these herein undiscussed topics.

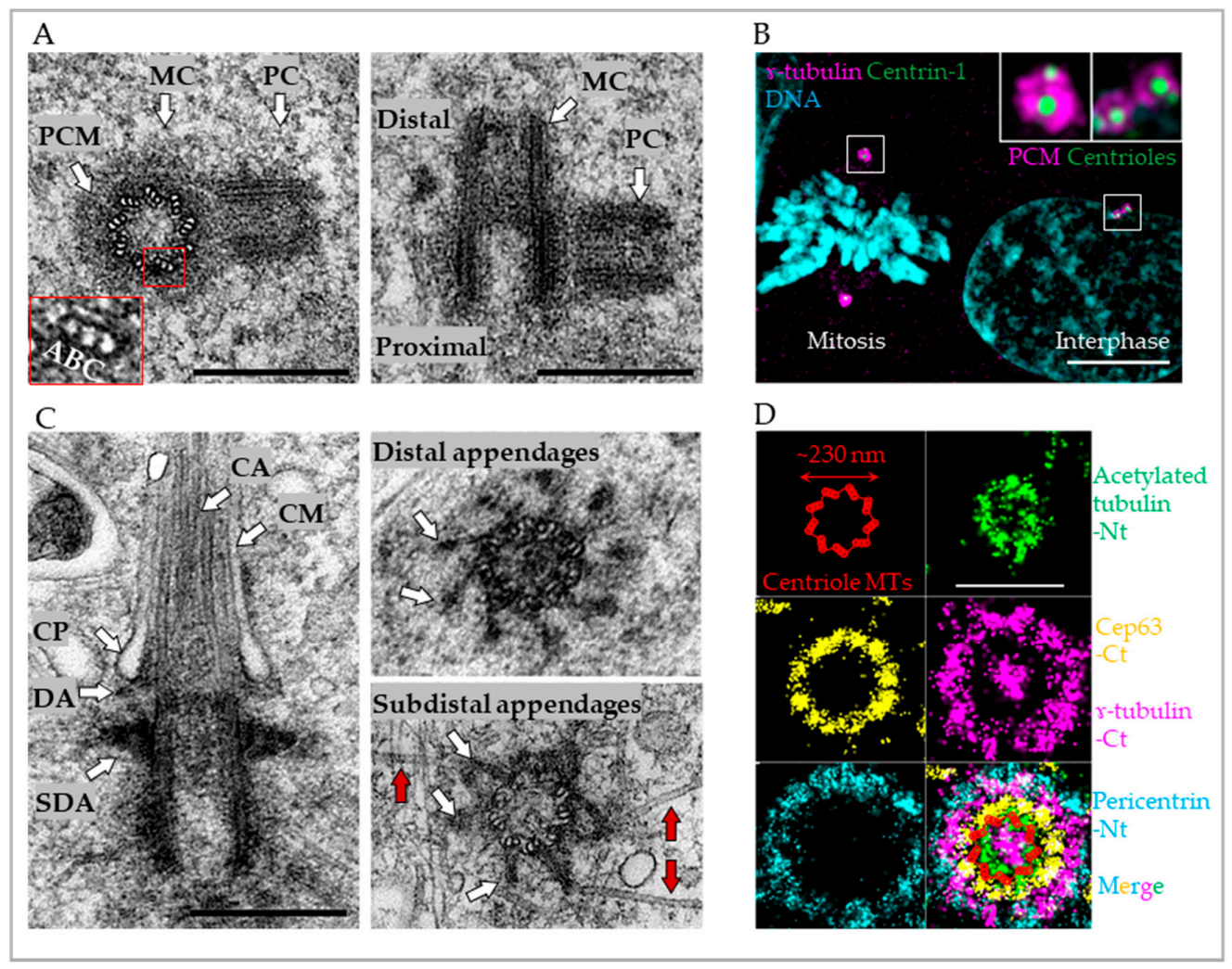

Figure 1. The organization of mature centrioles and centrosomes. (A) Left: Electron micrograph of a mother centriole (MC, in cross-section) associated with a procentriole (PC, in longitudinal section) from an mIMCD3 (mouse inner medullary collecting duct) cell. Pericentriolar material (PCM) is visible around the MC. One microtubule (MT) triplet built of A, B, and C MTs is enlarged in the red box. Right: Electron micrograph of a mother centriole (MC) and associated procentriole (PC) from an mIMCD3 cell. Both centrioles are sectioned longitudinally. (B) Centrosomes in mitotic or interphase human cycling retinal pigmental epithelial (RPE-1) cells. Two mitotic centrosomes have expanded pericentriolar material (PCM), here labeled by anti- $\gamma$-tubulin antibody, and are positioned on the opposite poles of the mitotic spindle. Each centrosome contains two centrioles, labeled with Centrin1-GFP. Chromosomes are aligning in the middle of the cell. In the interphase cell, two centrosomes, each harboring a duplicated mother centriole, are positioned near the nucleus and are associated with less abundant PCM. (C) Electron micrograph of a mature mother centriole with distal appendages (DA), subdistal appendages (SDA), and a cilium from a serum-starved RPE-1 cell. Ciliary axoneme (CA) is extending from the centriole distal end. DAs are adjacent to a ciliary pocket $(\mathrm{CP})$, which continues into the ciliary membrane (CM) and surrounds the CA. Right: Cross sections through the region of centriole containing DAs (top) or SDAs (bottom) associated with MTs (red arrows). Electron microscopy was performed as described in Ref. [18]. (D) A montage of Stochastic Optical Reconstruction Microscopy (STORM) images of four centrosomal proteins immunolabeled as indicated and superimposed, to illustrate toroidal organization of centrosomal components with respect to centriole MTs (red). STORM and conventional microscopy were performed as described in Ref. [19] and using the antibodies as follows: $\gamma$-tubulin: Sigma; T5326, Cep63: Millipore; 06-1292, Pericentrin: Abcam; ab4448, and acetylated tubulin: Sigma; T7451. Scale bars: $400 \mathrm{~nm}$ in (A and C); $5000 \mathrm{~nm}$ in (B); $400 \mathrm{~nm}$ in (D). 


\section{The Organization of Mature Centrioles and Centrosomes}

In this chapter, we will provide a brief description of mature centrioles and centrosomes of mammalian cycling cells. Typical mammalian centrioles are $\sim 230 \mathrm{~nm}$-wide and $\sim 500$-nm long cylinders. Their walls are built of nine sets of microtubule (MT) triplets made from one full MT (tubule A) and two partial MTs (tubules B and C), organized with a precise nine-fold symmetry (Figure 1A) [16,20,21]. Centrioles are polarized along their longitudinal axis. The PCM localized to the proximal end mediates centrosomal functions such as MT nucleation and the assembly of new centrioles (Figure 1A) [22,23]. Microscopy-based mapping of individual protein domains in sub-resolutional scale has revealed a fascinating order in the organization of PCM components. Using antibodies targeting different epitopes of the same protein or N-terminally and C-terminally fused fluorescent tags, microscopy reveals that numerous PCM components are arranged in an extended conformation with one part of the molecule closer to the centriole and the other extending into the PCM. Many PCM components often associate with both centriole MTs and other PCM components resulting in the distribution of PCM proteins in circles of discrete diameters surrounding the centriole (Figure 1D) [24-29].

On their distal end, fully mature centrioles carry two types of electron dense projections called distal and subdistal appendages (DAs and SDAs, respectively, Figure 1C). Distal appendages reflect the nine-fold organization of centrioles and they appear as nine $\sim 130 \mathrm{~nm}$-long electron dense protrusions forming $~ 100 \mathrm{~nm}$ from the distal centriole end [19-21]. During ciliation, DAs are required for the attachment of ciliary vesicles to centrioles and their subsequent fusion with the cytoplasmic membrane and are thus, essential for ciliogenesis [30-34]. Subdistal appendages, which are formed just below DAs, are usually robust electron densities that are highly variable in shape and in number (Figure 1C) $[35,36]$. On their periphery, SDAs are associated with MTs, which regulate MT centrosome positioning [37-41] and cohesion [42].

The exact number of centrosomal proteins is not known and varies between different cell types. While novel centrosomal proteins are still being discovered, about 200 core centrosome proteins (systematized in a centrosome data base, $[43,44]$ ) have been identified through proteomic analyses [45-48]. The stoichiometry and intra-centrosomal localization of centrosomal components changes during the cell cycle and is dependent upon regulated transcription, degradation, and posttranslational modifications [49-53].

\section{Assembly and Maturation of a Centriole Requires Three Consecutive Cell Cycles-A Brief Overview}

The centriole assembly process is unique amongst organelles in the sense that it requires three consecutive cell cycles to be completed. Once formed, centrioles persist through many generations of cycling cells [54]. The assembly of new centrioles (herein referred to as procentrioles) begins around the time of S phase entry in a process called centriole duplication (Figures 2 and 3). The exact timing of procentriole initiation is still debatable since some studies argue that it occurs in late G1 phase [55] and others in early $S$ phase $[20,56]$. While this conundrum still has to be resolved, in this review, we will adhere to the scenario that procentriole initiation occurs in early $S$ phase. During duplication, one new procentriole initiates orthogonally near the proximal region of each of the two resident centrioles (herein referred to as mother centrioles). After their initiation, procentrioles elongate during $\mathrm{S}^{1}, \mathrm{G} 2^{1}$, and mitosis ${ }^{1}$, and change their biochemical composition. They remain in the same centrosomal complex with mother centrioles until the end of mitosis $^{1}$, after which they physically separate (disengage [57]) and organize their own PCM components, establishing a centrosome. We will refer to such disengaged procentrioles as daughter centrioles. From $\mathrm{G}^{2}$ until the ensuing $S$ phase $\left(\mathrm{S}^{2}\right)$, the daughter centriole accumulates PCM components including those required for the initiation of their own procentriole. As a result, both the older mother centriole and the daughter centriole (from this point herein referred to as a younger mother centriole) duplicate upon $S^{2}$ phase entry (Figures 2 and 4 ). In the ensuing $\mathrm{S}^{2}$ and $\mathrm{G} 2^{2}$ phases, the younger mother centriole accumulates additional PCM allowing it to enter mitosis with levels of PCM comparable to the older mother centriole (Figures 2 and 4). In parallel to 
the maturation of their proximal end, in $\mathrm{G} 2^{2}$ phase, the distal end of a younger mother centriole begins to associate with a set of proteins that will result in the structuring of subdistal and distal appendages, which are responsible for MT anchoring and ciliation, respectively (Figures 2 and 4). Structuring of centriole appendages continues until $\mathrm{G}^{3}{ }^{3}$, and it represents the last step in the assembly of a centriole which was initiated two cell cycles ago. Only at this point has the centriole, and the centrosome which it organizes, gained a full range of functions.

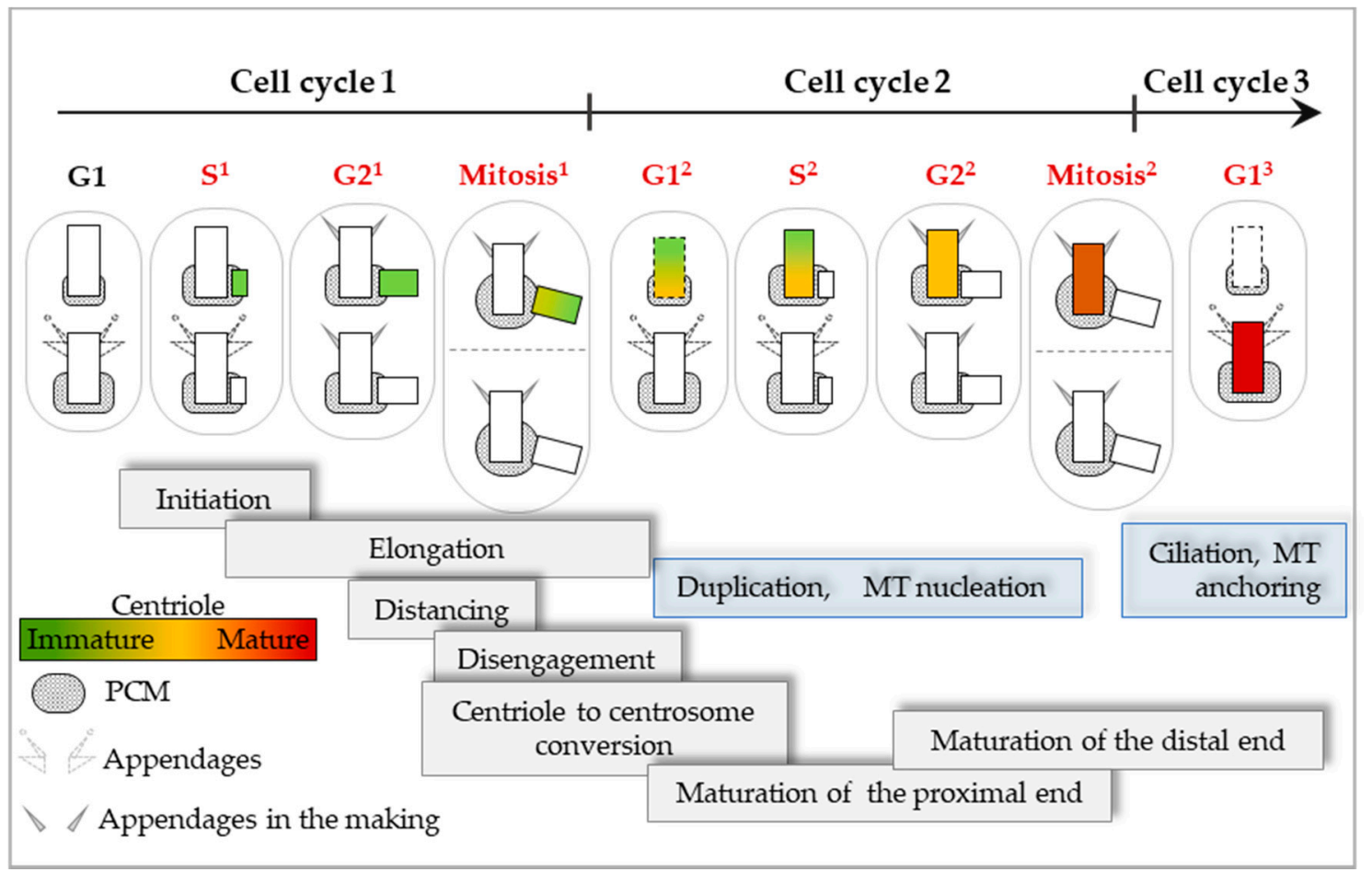

Figure 2. Assembly and maturation of a human centriole in cycling cells requires three consecutive cell cycles. After mitosis, cells inherit one partially mature and one fully mature centriole (with appendages). Both centrioles duplicate at the beginning of $S$ phase. Scheme emphasizes one centriole from its initiation (green) in $S$ phase of cell cycle $1\left(S^{1}\right)$ through its elongation and progressive maturation, until its final maturation in $\mathrm{G} 1$ of cell cycle $3\left(\mathrm{G}^{3}\right)$ (dark red with appendages). Gray boxes indicate the major assembly and maturation events that occur in each cell cycle. New functions acquired by the centriole at different stages of maturation are indicated by blue boxes, including duplication (cell cycle 2), MT nucleation (cell cycle 2), ciliation (cell cycle 3) and MT anchoring (cell cycle 3).

By staggering centriole maturation over three consecutive cell cycles and gradually adding specific functions to them, cells ensure that two centrioles/centrosomes are capable of duplication and spindle formation, but only one centriole, the oldest, can ciliate. Such an orderly assembly process is unique amongst organelles and is a result of a remarkable coordination between the cell cycle and the centriole cycle machinery [58,59]. 

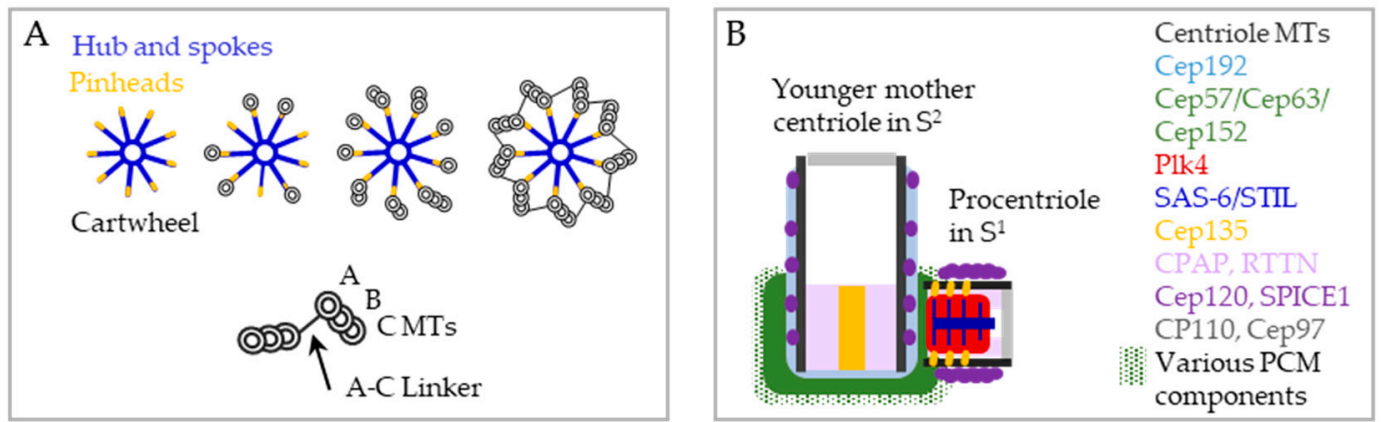

Figure 3. Procentriole initiation and MT assembly. (A) The first structure in the assembly of a procentriole is a nine-fold symmetrical cartwheel (top left). The three most distinguishable features of the cartwheel are the central hub, nine spokes, and nine pinheads that connect the cartwheel with microtubules. A, B, and C microtubules (MTs) are gradually assembled around the cartwheel. MT triplets are presumably stabilized by an A-C linker formed between the A and C MTs of adjacent MT triplets. The biochemical nature of the linker is unknown. (B) Localization of proteins involved in procentriole initiation and elongation on a mother centriole in $S^{2}$ and a procentriole in $S^{1}$. Mother centriole associated Cep192, Cep63, and Cep152 recruit Plk4 to the centrosome. After Plk4 associates with STIL, a Plk4/STIL focus assembles near the mother centriole and recruits cartwheel protein SAS-6 and Cep135. CPAP, Cep120, and SPICE1 promote centriole elongation while CP110 and Cep97, localized at the centriolar cap, prevent over-elongation.

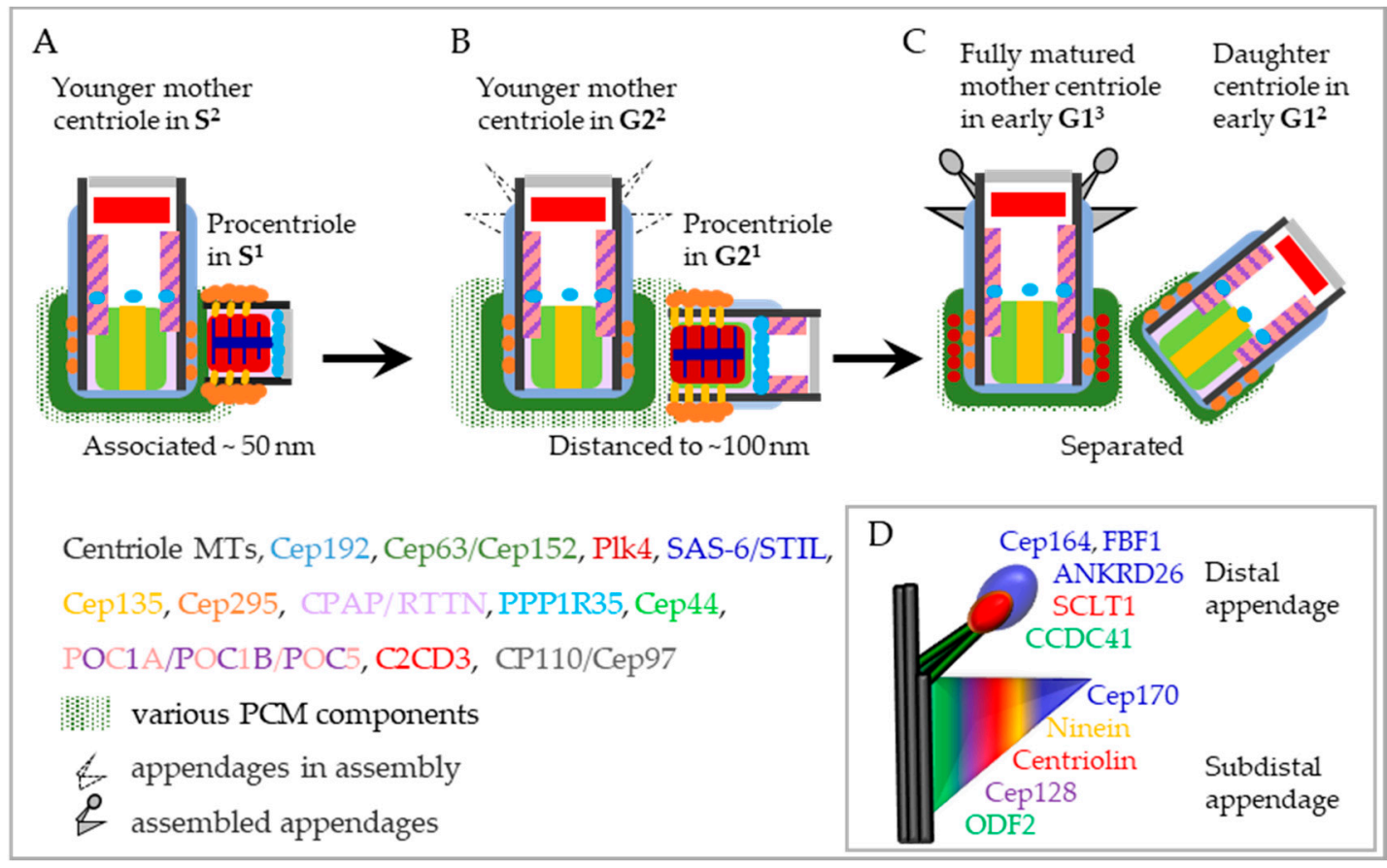

Figure 4. Localization of proteins involved in procentriole maturation from $S^{1}$ to $G 1^{2}$. (A) In $S^{1}$, the procentriole is adjacent to a mother centriole and lacks PCM. On their proximal end, in addition to the cartwheel, several proteins such Cep135, CEP295, CPAP, RTTN, and PPP1R35 are important for future procentriole stabilization. The younger mother centriole, in $\mathrm{S}^{2}$, is associated with PCM components and lower levels of Cep295 and PPP1R35. In addition, more distally, it contains POC1A/B, POC5, and $\mathrm{C} 2 \mathrm{CD} 3$, which are important for the assembly and organization of triplet microtubules. (B) In G2 ${ }^{1}$, procentrioles assemble their distal end, marked by the recruitment of new luminal proteins such as Cep44, POC1A/B, POC5, and C2CD3, which contribute to the structural integrity of the centriole. Additionally, Cep192 is recruited to the outer MT wall of the procentriole. The procentriole and the 
mother centriole are at a larger distance away from each other. In $\mathrm{G} 2^{2}$, the younger mother centriole accumulates more PCM components at its proximal end, and on its distal end, starts accumulating inner subdistal and distal appendage components. (C) In $\mathrm{G1}^{2}$, procentrioles, which lose their cartwheel in mitosis, stabilize by recruiting various PCM components. In $\mathrm{G}^{3}$, the younger mother centriole completes its maturation cycle by recruiting outer subdistal and distal appendages. (D) Localization of appendage proteins on fully mature mother centriole in $\mathrm{G}^{3}$.

\section{Morphological and Biochemical Changes of Centrioles during Assembly and Maturation}

In this chapter, we will discuss the milestones, as well as the ultrastructural and biochemical changes, that occur on a typical centriole in a cycling somatic human cell, from its procentriole stage until its final transformation into a fully mature centriole.

\subsection{From Procentrioles to Daughter Centrioles}

\subsubsection{Procentriole Initiation-Ultrastructural Aspect}

By electron microscopy, newly formed procentrioles can be detected $\sim 50 \mathrm{~nm}$ from the proximal end of mother centriole wall. They appear as electron dense $190 \mathrm{~nm}$-wide circular assemblies that contain a centrally positioned nine-fold-symmetrical cartwheel and surrounding electron dense material, where nine sets of MT singlets, doublets, or triplets can be observed, depending on the stage of their development (Figure 3A). The procentriole cartwheel (reviewed in $[60,61]$ ) has three clearly distinguishable ultrastructural elements: a $\sim 22 \mathrm{~nm}$-wide central hub, nine spokes which radially emanate from the hub, and nine pinheads which connect the distal ends of the spokes with the procentriole's innermost tubule, the A tubule (Figure 3A) [20,21,62].

A major component of the cartwheel is the protein SAS-6, which oligomerizes to generate a hub and nine spokes that emanate out of it. It is likely that another component of the spokes and the pinhead structure is Cep135 (Bld10p in Chlamydomonas and Bld10 in Drosophila [63-67]). The cartwheel provides stability and nine-fold symmetry to centrioles and is considered to be a scaffold for the formation of procentriole MTs. Both SAS-6 and Cep135 are necessary for procentriole assembly [68,69]. However, in human and Chlamydomonas cells carrying various SAS- 6 and Cep135 mutations, cartwheel symmetry is perturbed, yet centriole MTs can still form as do procentrioles, albeit with a lower precision $[66,70,71]$. The cartwheel elongates during the cell cycle and by the end of $\mathrm{G} 2^{1}$ phase it occupies $\sim 180 \mathrm{~nm}$ of a procentriole's $\sim 280 \mathrm{~nm}$ length [72].

Ultrastructural studies of mammalian procentrioles show that MT triplets form progressively: the first to form is the A tubule, followed by the B, and C tubules. Cryo-electron tomography of procentrioles isolated from human lymphoblastoid cells [73] suggests that the A tubule elongates in a proximal-distal direction and serves as a template for the assembly of the B tubule, the elongation of which can be bidirectional. Similarly, the B tubule then templates bidirectional assembly of the $C$ tubule. The formation of each MT triplet in human procentrioles is suggested to be independent [73] contrary to the synchronous buildup of all nine MT blades seen in some other species [74]. Additional analysis would be needed to understand whether this scenario of tubule incorporation universally applies to procentrioles in all human cell types. The literature offers ample descriptions of human procentrioles at stages containing MTs, but early stage procentrioles without MTs are poorly documented by electron microscopy, indicating that MT incorporation occurs relatively rapidly after procentriole initiation. However, a precise timing of A, B, and C tubule incorporation during the cell cycle still needs to be unraveled.

Once procentriole MT triplets are assembled, the inner A tubule and the outer C tubule from the adjacent MT triplets are connected by a linker (Figure 3A), which remains detectable on the proximal end of the centriole thereafter $[20,21,62,75-77]$. The composition and the exact function of the A-C linker are not known. POC1 has been proposed as a potential linker protein since, in Tetrahymena, its depletion slightly perturbed inter-triplet linkage and the integrity of basal bodies [78]. In addition 
to the more proximal A-C linker, there are additional electron densities that connect adjacent $\mathrm{A}$ tubules on the middle and distal parts of centrioles [20,79].

Until mitosis ${ }^{1}$, the angle between a MT triplet and the procentriole radius passing through the A tubule is smaller $\left(\sim 30^{\circ}\right)$ than that of mature centrioles $\left(\sim 45^{\circ}\right)$. In vertebrates, the cartwheel disappears from procentrioles in mitosis ${ }^{1}$, which is accompanied by a slight widening of the procentriole lumen and a change in the radial angle of procentriole MT triplets, such that by the end of mitosis ${ }^{1}$, a procentriole's diameter is similar to the diameter of mature centrioles $[20,80]$.

\subsubsection{Procentriole Initiation: Regulation and Required Proteins}

Cartwheel assembly, which marks procentriole initiation, is triggered by the interaction of Polo-like kinase 4 (Plk4 [81], SAK in Drosophila [82], and Zyg-1 in C. elegans [83]) and SCL-interrupting locus protein (STIL [84,85], Ana-2 in Drosophila [86-88], and Sas-5 in C. elegans [89]), a procentriole initiator whose levels rise in the cytoplasm of cells approaching $S$ phase $[90,91]$. In proliferating cells, Plk4, which is always present in the cytoplasm, regulates both its activity and its levels through trans-autophosphorylation of its kinase domain and autophosphorylation of its degron [92-98]. Its centrosomal localization is mediated by PCM components Cep192, Cep57, Cep63, and Cep152, which are localized around the proximal ends of mother centrioles (Figure 3B) [27,99-102]. On unduplicated mother centrioles in G1 phase, Plk4 is distributed around the proximal end of centrioles [103]. As cells approach S phase, Plk4 and STIL begin to associate. Phosphorylation of STIL by Plk4 further promotes their association and, in addition, protects Plk4 from degradation, resulting in an increase in the local Plk4/STIL concentration [104-108] and a change in Plk4 localization from a ring around the mother centriole to a single focus [103]. Once a PLK4/STIL focus is established in the vicinity of the mother centriole, the formation of other foci is inhibited by a still poorly understood molecular mechanism (for discussions see [85,109-112]). Phosphorylated STIL additionally recruits SAS-6 to the Plk4/STIL focus $[105,106,113]$. This promotes the self-oligomerization of SAS-6 into a nine-fold cartwheel scaffold that demonstrates lateral stacking and associates with other centriolar components (Figure 3) [70,114,115]. Downstream from Plk4/STIL/SAS-6-driven cartwheel assembly, the incorporation of other proteins such as Centrosomal-P4.1-associated-protein CPAP (also known as CENPJ and SAS-4 in Drosophila and C. elegans), is needed to start the assembly of procentriole MTs. Interestingly, it was recently shown that phosphorylation of STIL by Plk4 also plays an important role in the recruitment and stabilization of CPAP [116].

\subsubsection{Proteins Involved in Procentriole Elongation}

Like cytoplasmic MTs, centriole MTs are also built of $\alpha$ - and $\beta$-tubulins. However, while cytoplasmic MTs are highly dynamic, centriole MTs are stable and once formed do not exchange tubulin with the cytoplasmic pool $[117,118]$. In mammalian cultured cycling cells, most procentriole MT growth occurs from early $S^{1}$ until the end of mitosis ${ }^{1}[20,72,117,119,120]$. Available studies disagree about whether mammalian procentrioles grow to their final length before or after $\mathrm{G}^{2}$, although this disagreement may reflect cell type-specific differences in the dynamics of procentriole elongation or variability in experimental approaches used to assess centriole length. For instance, in human HeLa cells, procentrioles reach $\sim 75 \%$ of their future length by mitosis ${ }^{1}$, and elongate to $\sim 85-90 \%$ of their final length by the end of mitosis ${ }^{1}$ [72], similar to human lymphoblastic cells KE37 cells [119]. Centrioles of porcine kidney epithelial LLC-PK cells, on the other hand, do not incorporate biotinylated tubulin after $\mathrm{G1}^{2}$ [117].

It is still unknown what imparts this slow growth and stability to procentriole MTs or how centriole elongation is regulated. One major difficulty in studying procentriole elongation is that during procentriole assembly, elongation of MTs occurs in parallel with their stabilization and the procentriole's biochemical maturation. In addition, the same proteins can be involved in several parallel processes during procentriole assembly. For instance, CPAP is needed for procentriole initiation, 
MT elongation, and PCM tethering to centrioles [91,121-126]. So, it is often impossible to perturb only one aspect of early procentriole assembly without affecting another.

In terms of its role in MT elongation, one of the best characterized proteins is CPAP. In humans, CPAP localizes in the lumen of procentrioles and in the lumen and PCM of mother centrioles (Figure 3B) [24,68]. CPAP associates with multiple procentriole-associated proteins such as Cep120, SPICE, Cep135, and Centrobin, which all contain MT-binding domains and positively regulate procentriole elongation [121-123,127-130]. Depletion of either CPAP, Cep120, SPICE1, or Cep135, or overexpression of CPAP or Cep120, results in shorter or elongated centrioles, respectively. On its $\mathrm{N}$ terminus, CPAP contains a MT binding domain (MBD) and an $\alpha / \beta$-tubulin binding domain (PN2-3), which are both required for MT elongation [123,131-133]. The C-terminal portion of PN2-3 is suggested to act as a molecular lid which restricts MT growth [131,132]. However, how the PN2-3 region is regulated in vivo and how CPAP operates in the context of other centriolar proteins required for procentriole elongation is not clear.

Two proteins that 'cap' distal centriole ends, CP110 and Cep97, counteract elongation of centriole MTs and their depletion results in over-elongation of centriole MTs, mimicking the effects of CPAP overexpression $[122,134,135]$. Over-elongation of older centrioles is also somehow counteracted by a component of the distal centriole end, Ofd1 [136]. Finally, a group of centriolar proteins including RTTN [137] (Ana3 in Drosophila [138]), PPP1R35 [139,140], Cep295 [141], POC5 [142], and C2CD3 [143,144], which are situated in the vicinity of procentriole MT walls, are all critical for the formation of full-length centrioles. RTTN, Cep295, and PPP1R35 are incorporated at the proximal ends of procentrioles in $\mathrm{S}^{1}$ phase, while POC5 and C2CD3 are incorporated in $\mathrm{G}^{1}$ phase and are more distal (Figure 4). It is possible that at least some of these proteins contribute to centriole elongation by promoting their overall structural integrity and maturation rather than being directly involved in MT nucleation (discussed in Chapter 5).

\subsubsection{Regulation of Procentriole Elongation}

Centriole length is considered to be relatively constant for a particular cell type, although it may drastically vary between cell types of the same organism and between species. Centrioles of somatic human cells are $\sim 500 \mathrm{~nm}$-long, but it is not understood how centrioles achieve this target size. In Drosophila embryos, where the cartwheel occupies the entire length of $\sim 200 \mathrm{~nm}$-long centrioles, the rate and the period of procentriole elongation is regulated by Plk4, the same kinase that is responsible for cartwheel initiation [145]. However, human centrioles are longer, and their cartwheel occupies only the proximal procentriole end, meaning that their distal end, which elongates in G2 ${ }^{1}$ phase and mitosis ${ }^{1}$, elongates beyond the cartwheel and in association with a different set of luminal and MT-associated proteins (Figure 4). Recent analysis of a series of human cell lines showed that in the same cell population, and sometimes within the same cell, mature and functional centrioles can range in their length from $\sim 330$ to $\sim 600 \mathrm{~nm}$ [72]. Further, arresting cells in G2 phase and mitosis, two cell cycle phases that normally support faster procentriole elongation [72], resulted in a stochastic over-elongation of procentrioles. The extent of over-elongation was variable between cells of the same population and between different cell types. This implies that human cycling cells do not have an active monitoring system for centriole length. Instead, the rate of centriole growth could depend on the local stoichiometry of elongation factors and the time a centriole spends in a specific phase of the cell cycle.

Two members of the Polo-like kinase family, Plk1 and Plk2, have been shown to positively regulate procentriole elongation in human cells [72,146]. In cycling human cells, the activity of Plk1 is low in G1 and early $S$ phases, increases in late $S$ and G2 phases, and peaks around the time of mitotic entry [147]. Plk1 is mostly known for its mitotic function and mitotic maturation of centrosomes [148-151]. However, Plk1 inhibition from early $S^{1}$ phase yielded procentrioles with shorter cartwheels and shorter MTs in mitosis and prevented procentriole over-elongation during mitotic arrest. Over-expression of Plk1 in cycling or S phase arrested human cells yielded longer than average centrioles with longer distal 
and/or proximal ends and displaced appendages [72]. In cycling cells, the peak of Plk1 activity also coincides with the faster phase of procentriole elongation. So, it is plausible that in human cells, Plk1, similarly to Plk4 in Drosophila [145], influences the rate of centriole elongation. Plk1 inhibition could reduce but not prevent procentriole elongation, suggesting that in human cells multiple regulators participate in centriole elongation. It is yet to be understood how Plk1 and Plk2 influence centriole elongation, but it is noteworthy that both kinases can phosphorylate CPAP [146,152]. Plk2, which is mostly active in early $S$ phase [153], promotes procentriole elongation through phosphorylation of CPAP S589 and S595 [146], although further molecular mechanisms are unknown.

\subsubsection{Mother Centriole-Procentriole Distancing and Separation}

Procentrioles form in the vicinity of the proximal end of mother centrioles. Under physiological conditions, procentrioles form $\sim 50 \mathrm{~nm}$ from the mother centriole MT wall (Figures 1A and 4A). When the procentriole is closely associated with the mother centriole, the two are said to be engaged. Maintaining a close association between a mother centriole and a procentriole during interphase is a critical factor in regulating centriole number, since the presence of the procentriole inhibits mother centriole reduplication. This centrosome intrinsic block to mother centriole reduplication was originally proposed by Wong and Stearns [154], who showed, performing a series of cell fusion experiments, that only mother centrioles which were not associated with procentrioles could duplicate in a duplication-permissive environment. Ablations of procentrioles from mother centriole-daughter complexes using a laser microbeam further established that inhibition of mother centriole reduplication originates from the presence of a procentriole in its vicinity [155]. Additionally, a series of chemical and genetic manipulations of Plk4 and STIL established that phosphorylation of STIL by Plk4 is required for its maintenance at the procentriole [106] and for the sustained reduplication block [156].

As the cell cycle progresses, the physical distance between the procentriole and the mother centriole increases and by the end of $\mathrm{G}^{1}$ (prophase), the distance between the centrioles can reach $>100 \mathrm{~nm}$ (Figure 4B) [20,157]. At this stage, the proximal ends of procentrioles are still embedded in the mother centriole PCM, which begins to expand in preparation for mitosis. It is not clear whether such distancing occurs gradually or abruptly in G2, but it has been shown that it requires Plk1 [157]. The importance of a tight mother centriole-procentriole association during interphase becomes obvious in the context of pathological reduplication of centrioles, which is also promoted by Plk1. Analysis of reduplicating centrioles by time-lapse microscopy [155] and correlative time-lapse electron microscopy [157] revealed that premature distancing of procentrioles to $\sim 80-90 \mathrm{~nm}$ precedes, and is necessary, for centriole reduplication. It is not clear how Plk1 drives mother centriole-procentriole distancing during interphase, but one hypothesis is that Plk1 promotes unscheduled procentriole maturation program (regulation of procentriole maturation by Plk1 is discussed in Chapter 5), leading to their premature ousting from the mother centriole PCM due to spatial limitations created by the growing PCM of the maturing procentriole [157]. However, this hypothesis needs to be experimentally corroborated.

After mitotic entry until anaphase, two distanced centrioles still move as a part of the same centrosome, although their association within the centrosome is no longer stringent [157], suggesting that the two centrioles are only loosely held together by the expanded PCM. Indeed, in cells depleted of the PCM component Pericentrin, centrioles tend to prematurely separate during mitosis [158]. After the metaphase to anaphase transition, concomitantly with postmitotic PCM disassembly, two distanced centrioles finally separate and assemble independent PCM (Figure 4C). By electron microscopy, separated G1 centrioles have usually lost orthogonal orientation, with respect to the mother centriole, and are generally at an increased distance from one another. This final separation step marks the end of centriole engagement.

Plk1 is also thought to participate in the final separation of centrioles in late mitosis $[159,160]$. Plk1-mediated phosphorylation of Pericentrin in mitosis and its subsequent cleavage by the cysteine protease Separase was shown to be important for the ability of centrioles to separate and duplicate in the subsequent cell cycle [160-162]. However, Separase involvement in centriole separation may not 
be absolutely required or universal. For instance, in human HT116 cells, inactivation of the Separase gene slowed but did not prevent disengagement [159] and in C. elegans embryos, depletion of Separase affected centriole disengagement in meiotic but not in mitotic cycles [163]. Further, cleavage of cohesin by Separase was found to be a critical factor for centriole disengagement in U2OS cells [164], but not in HCT116 cells [159] or flies [165]. Thus, more work will need to be done to dissect the events which regulate a timely separation of mother centrioles and procentrioles in mitosis and G1.

\subsubsection{Stabilization and Maturation of Disengaged Procentrioles in $\mathrm{G}^{2}{ }^{2}-$ Centriole-to-Centrosome Conversion}

From $S^{1}$ until the end of mitosis ${ }^{1}$, procentrioles do not have the ability to nucleate MTs $[166,167]$ and are not known to perform any function. During that time, procentrioles need to elongate and structure their MT wall. However, they also need to acquire a set of biochemical modifications, which will enable them to accumulate PCM, become stable, and to duplicate once they disengage from mother centrioles. This part of the procentriole maturation process is known as centriole-to-centrosome conversion (CCC) [166]. CCC is not well understood on a molecular level, but removal of several centriolar proteins, which are localized in the procentriole's lumen or adjacent to their MTs, interferes with conversion, leading to the destabilization and loss of procentrioles after mitosis ${ }^{1}$.

In humans and Drosophila, CCC requires molecular interactions between Cep135/Bld10 and Cep295/Ana1, which associate through their N-terminal regions localized adjacent to procentriole MTs (Figure 4) [168,169]. Cep295/Ana1 is thought to bridge the centriole lumen with the centriole periphery and PCM components, which can explain why centriole's lacking Cep295/Ana1 fail to undergo CCC. Indeed, loss of Cep295 prevents recruitment of Cep192 [170], which in human cells localizes at procentrioles in G2 ${ }^{1}$ phase and is important for recruitment of PCM components including duplication factor Cep152 [103,171-173]. Similarly, in flies, Ana1 is needed for recruitment of duplication factor Asterless $[168,169,174,175]$. Cep295/Ana1 incorporates at the proximal ends of procentrioles during $S^{1}$ phase $[141,168,170,176]$. In human cells, procentriole destabilization due to Cep295 depletion was prevented if procentrioles retained their cartwheel after mitosis ${ }^{1}$ [176]. However, in flies, where centrioles do not physiologically lose their cartwheel after maturation, Ana1-negative centrioles were still lost from the population [168]. Thus, in this system, the cartwheel could not compensate for the loss of CCC. It is important to note, however, that Cep295-negative procentrioles with a cartwheel were not followed past $\mathrm{G} 1^{2}$ phase, so it is not clear whether they would remain stable during further cell cycle progression.

Cep295/Ana1 depletion additionally results in the formation of short and MT-less procentrioles, while overexpression of Cep295/Ana1 resulted in longer centrioles [141,168]. Further, short procentrioles lacking Cep295 also failed to incorporate more distally positioned inner scaffold proteins POC1B and POC5 [141,177]. Centriolar Cep295 levels can also be perturbed by depletion of PPP1R35 [139], which is enriched in the procentriole proximal lumen above the cartwheel and is required for structuring of procentriole distal ends (Figure 4B) [140]. It is not clear how PPP1R35, which is recruited to procentrioles more distally than Cep295 [140], interferes with Cep295 localization. Finally, depletion of Cep44, a POC1B interacting protein that associates with G2 procentrioles in a Cep295-dependent manner, perturbs centriole MT arrangement and leads to the loss of centrioles [178]. In Cep44 depleted cells, Cep295 was still localized to procentrioles, but was not sufficient for CCC in the absence of procentriole MT integrity. Consistent with this result, centriole destabilization also occurs after co-depletion of POC1A and POC1B [179]. Cep135/Bld10 and POC1 are also required for the assembly and maintenance of triplet MTs of the centriole/basal bodies in Tetrahymena and Paramecium [78,180,181]. Cep295 is not conserved in nematodes but in C. elegans, SAS-7, which localizes proximal to the MT wall, fulfills a similar role in regulating centriole structure and recruitment of the Cep192 homolog Spd-2 [182]. Finally, centrioles are also lost in human cells lacking $\varepsilon$ - and $\delta$-tubulin. In these cells, procentrioles form in every cell cycle, but they do not form triplet MTs, fail to incorporate PCM components, and destabilize after mitosis ${ }^{1}$ [183]. Clearly, we are only starting to understand how centriole structural 
integrity relates to CCC, both of which depend on the concerted action of numerous centrosomal proteins localized near procentriole MTs that bridge the centriole lumen with its periphery.

\subsection{From Daughter Centrioles to Mother Centrioles and Basal Bodies}

From $\mathrm{G} 1^{2}$ until $\mathrm{G} 1^{3}$, disengaged and stabilized daughter centrioles continue to mature, which manifests through the loss or recruitment of various proteins (Figure 4). Biochemical and structural asymmetries between the daughter centriole and older mother centriole are reduced by $\mathrm{G}^{3}$, leaving the two centrioles almost indistinguishable from each other.

\subsubsection{Acquiring the Ability to Duplicate, Nucleate Microtubules, and Form a Mitotic Spindle Pole}

In $\mathrm{G}^{2}$ phase, the daughter centriole can be distinguished from the mother centriole by lower levels of PCM components [167] and, at least in some cell types, by highly motile behavior in comparison to the mother centriole [38]. The centrosome organized by the mother centriole is surrounded by an array of nucleated and anchored MTs, while the daughter centriole has little or no ability to anchor and nucleate MTs [38]. A molecular linker composed of C-NAP1 (CEP250), Rootletin, CNTLN, Cep68, and several other proteins establishes a connection between the two centrosomes [41,184-188] such that the two PCMs organized by each centriole remain adjacent but autonomous. The inter-centrosomal linker is dissolved in G2 phase, allowing the two centrosomes to move away in preparation for mitosis. Mutations and disruptions of the centrosomal linker are associated with genetic disorders and chromosomal instability as reviewed in [184]. For instance, C-NAP1 mutations cause Seckel-like syndrome in cattle [189] and Usher Syndrome in humans [190]. A splice mutation in Rootletin promotes chromosomal instability and chromosome segregation defects in human colorectal cancer cells [191].

The post-mitotic daughter centriole is considered duplication incompetent because it is associated with little or no Plk4. In human cells, Plk4 is recruited through two recruiting factors, Cep192 and Cep152 [100,101,192], which compete for binding to the cryptic polo box domain of Plk4 [103]. While the daughter centriole is associated with Cep192 immediately after mitosis, Cep152 is gradually recruited to the proximal end by its association with Cep63 [28,99]. Cep63, in turn, binds inner PCM protein Cep57, which anchors the Cep63/Cep152 complex to the centriole [27,193]. Per one model [102], Plk4 is initially recruited by Cep192 closer to the centriole, but is repositioned further from the centriole later in G1 as the Cep57/Cep63/Cep152 complex accumulates at the centriole $[103,194,195]$ and Cep152 competes with Cep192 for Plk4 binding.

In addition to duplication factors, throughout $\mathrm{G}^{2}, \mathrm{~S}^{2}$, and $\mathrm{G}^{2}$, the daughter centriole (later the younger mother centriole) continues to accumulate other PCM components such as $\gamma$-tubulin, Cep192, Pericentrin, and Cdk5Rap2 (Cep215), which eventually renders it competent for MT nucleation. Finally, before mitosis ${ }^{2}$, PCMs of both the older and the younger mother centriole expand in size in a process called centrosome maturation (Figures 2 and 4) [196-198]. This process transiently increases the MT-nucleating capacity of centrosomes, promoting formation of two poles of the mitotic spindle. Centrosome maturation is largely driven by the activity of Plk1 [151], which peaks at the time of prophase [147]. Before mitosis, two mother centrioles accumulate comparable levels of PCM components. This is important for the symmetric organization of the mitotic spindle, accurate segregation of genetic material, and for generating two equal somatic sister cells with similar proliferating potential. Nevertheless, some functional asymmetries between the older and the younger centrosome still persist in mitosis, biasing chromosome segregation [199]. Biochemical and functional asymmetry between two centrosomes is also enhanced and used to generate asymmetric cell divisions during embryonic development, tissue regeneration, morphogenesis, or to influence cell geometry and function [200-203].

\subsubsection{Assembly of Subdistal and Distal Appendages}

The assembly of centriole subdistal and distal appendages (SDAs and DAs, respectively), which starts in $\mathrm{G}^{2}{ }^{2}$, continues through mitosis and finishes in $\mathrm{G1}^{3}$, represents the end of the centriole's 
assembly and maturation process (Figure 4). By electron microscopy, SDAs manifest as robust, often striated, usually cone-shaped dense structures emanating from the centriole's wall 150-170 nm from the centriole distal end (Figure 1C) [20,36]. The number and shape of SDAs is highly variable [35,36] even between the cells of the same cell type. The ends of SDAs are associated with MTs [39,40], which mediate centrosome positioning, directional cell migration, and centrosome cohesion [37,204,205]. DAs are positioned distally to SDAs [19-21,36,79] and look like nine finger-like protrusions, slightly curved toward the centriole distal end [19] (Figure 1A). They have a triangular fibrous base associated with two adjacent MT triplets, a narrower stem, and an electron denser head [19]. DAs are essential for ciliogenesis since they mediate the attachment of ciliary vesicles to mother centrioles and their subsequent fusion with the cytoplasmic membrane (Figure 1C) [31-34,206-208].

Accumulation of SDA and DA components begins on younger mother centrioles in $\mathrm{G}^{2}$ and it involves a sequential incorporation of these components from the centriole's MT wall toward the periphery [19,31,209-211]. The assembly of SDAs is initiated by the recruitment of Odf2 around the centriole's MTs in G2 ${ }^{2}$, followed by the sequential recruitment of SDA components Cep128, CCDC68, CCDC120, Nde1, Centriolin, Ninein, and Cep170 (Figure 4D) [209,211,212]. The assembly of DAs starts with the recruitment of C2CD3, followed by CCDC41/CEP83 in G2 ${ }^{2}$. These are inner DA components, localized closer to the centriole wall $[19,210]$. CCDC41 is needed for the recruitment of CCDC123/Cep89 and SCLT1. The recruitment of SCLT1 begins in late $\mathrm{G}^{2}$ and is, in turn, needed for the recruitment of the outer DA components FBF1 and Cep164 [31] in late mitosis ${ }^{2}$ [19]. Similar timing of the recruitment of DA components to younger mother centrioles has recently been corroborated by [213]. The accumulation of DA components and their organization in a nine-fold symmetrical pattern is continuous throughout mitosis ${ }^{2}$ and for outer DA components even in early $\mathrm{G}^{3}$, as demonstrated by the use of super resolution imaging [19].

In cycling cells, both types of appendages present on mature centrioles in $\mathrm{G} 1, \mathrm{~S}$, and the beginning of G2 undergo a transient remodeling at the end of each cell cycle. SDA electron densities become undetectable in G2, remain undetectable throughout mitosis, and re-appear again in G1. Similarly, DA electron densities become less conspicuous in late G2 and mitosis, and gain their recognizable electron density in the ensuing early G1 [19]. Such diminished detectability of appendages in G2 and mitosis is a consequence of displacement of some appendage components from appendage sites. For instance, in G2, SDA components Cep170 [214] and Ninein [215] relocate from SDAs to the PCM, while Odf2, which is localized adjacent to the centriole, remains associated with centrioles during the entire cell cycle and even increases in intensity in mitosis $[19,213]$. Similarly, outer DA components Cep164, FBF1, ANKRD26, and TTBK2 dissociate from DAs in G2 and start reaccumulating in late mitosis $[19,213,216]$. However, DA inner components, CCDC41 and SCLT1, remain permanently associated with mature centrioles $[19,213]$ and are organized in their typical nine-fold pattern [19]. Based on super resolution analyses and the co-localization of CCDC41 and SCLT1 with the DA's electron dense base, it has been proposed that the inner appendage proteins may serve as a permanent DA scaffold for recruitment of more dynamic, functional outer appendage components [19].

It is not exactly clear why both types of appendages undergo pre-mitotic remodeling. However, it is important to note, that by the end of mitosis, the older and younger mother centrioles still retain certain functional asymmetries. For instance, in RPE-1 cells, the sister cell that inherits the older mother centriole after mitosis tends to grow a primary cilium sooner than its sister harboring the younger mother centriole [217]. So, it has been suggested that pre-mitotic DA remodeling could serve to reduce the age difference between two mother centrioles during mitosis and in early G1 [19]. According to this idea, a transient dismantling of appendages on the older mother centrioles would serve to balance appendage-associated functions between the two sister cells in early G1, before the younger mother centriole's SDAs and DAs are fully assembled. Indeed, this hypothesis has recently received a direct confirmation [213]. Dissociation of DA components before mitosis was abolished by inhibition of Nek2 kinase activity and perturbed the resorption of primary cilia, which normally occurs by prophase. This in turn, resulted in the asymmetric inheritance of ciliary signaling components and a faster cilium 
reassembly after cell division [213]. Delayed cilia resorption and retention of Cep164 on appendages throughout mitosis was also observed after Plk1 inhibition $[19,213]$. This data is compatible with the role of both mitotic kinases in reorganization of mother centriole components before mitosis [218]. It has yet to be understood whether transient remodeling of appendages on the older mother centrioles serves to balance other centriole-associated functions between the two sister cells.

\section{Regulation of Centriole Maturation by Plk1}

How procentriole assembly and maturation are gradually regulated through three cell cycles is not clear. Centriole maturation follows a strict cell cycle-dependent timeline, and kinases, especially Plk1, seem to play important roles in regulating procentriole maturation in both human $[166,219]$ and Drosophila cells [220]. Plk1 does not seem to be required for procentriole initiation, which occurs normally in the presence of Plk1 chemical inhibitors [72,155]. However, Plk1 is necessary during $\mathrm{G} 2^{1}$ phase and mitosis ${ }^{1}$ for some aspects of the centriole maturation process, since its inhibition during that time abrogates centriole-to-centrosome conversion [166]. Furthermore, inhibition of Plk1 during a centriole's second cell cycle, after CCC has occurred, prevents the assembly of centriole distal appendages, meaning that in cycling cells, Plk1 activity is still needed for maturation of distal ends of daughter centrioles [219].

Conversely, untimely expression of exogenous, active Plk1, which abolishes the physiological periodic activity of Plk1 in cycling cells, accelerates maturation of procentrioles and daughter centrioles, erasing the age difference between resident centrioles [219]. Consequentially, cells acquire supernumerary mature centrioles that form additional primary cilia and increase the overall centriole number due to precipitous distancing of procentrioles and reduplication of mother centrioles. Similarly, in non-cycling, S phase arrested cells, ectopic Plk1 expression induces procentrioles to complete their maturation cycle within one cell cycle, without transition through mitosis. During such an accelerated maturation process, procentrioles undergo typical biochemical and ultrastructural changes associated with physiological procentriole maturation: elongation; acetylation and polyglutamylation of procentriole MTs (as described in the ensuing chapter); association with PCM components; distancing and separation of procentrioles from mother centrioles; licensing for duplication through accumulation of Cep192, Cep63, and Cep152; loss or reduction of procentriole-elongation factors such as Cep120 and Centrobin [221,222]; and assembly of appendages [157,219]. Interestingly, one of the manifestations of procentriole maturation is a robust localization of Plk1 along centriole MT walls, which is barely detectable on immature procentrioles [157]. After its initial recruitment, Plk1 remains associated with mature centrioles. How Plk1 is first recruited to human procentriole MTs is unclear but in flies it requires SAS-4/CPAP $[157,220]$. Biochemical modifications that occur during centriole maturation appear to be stable, since fully mature centrioles can be maintained after an extended period of Plk1 inactivity [72]. It remains to be understood how exposure to Plk1 modifies centrioles, but one possibility is that Plk1-driven phosphorylation promotes interactions between some centriolar proteins situated on both sides of centriole MTs. Indeed, Plk1 localization along centriole MT walls would perfectly serve this purpose, although at a sufficient concentration, Plk1 could also induce maturation by promoting interactions of centrosomal proteins in the cytosol. It will be fascinating to learn how Plk1 regulates these interactions.

The role of Plk1 in centriole maturation is not limited only to cycling cells. There are specialized, terminally differentiated, multiciliated cells which produce a large number of procentrioles that mature and convert into basal bodies and assemble motile cilia [223-226]. In multiciliated mouse brain cells, Plk1 is involved in centriole elongation, procentriole distancing, maturation, and migration to the cell surface, which are all critical for multiciliation $[227,228]$.

It is unclear why human procentrioles formed in the absence of Cep295, POC1A/B, PPP1R35, Cep44, or $\varepsilon$ - and $\delta$-tubulins fail to undergo CCC even after exposure to Plk1. However, one common theme which emerges from ultrastructural and microscopy analysis of centrioles in cells depleted for these proteins is that they all carry some type of biochemical or centriolar structural defect, even 
before they were exposed to increased Plk1 activity that would normally result in their maturation and stabilization. Such structural defects may prevent Plk1 from being recruited to procentriole MTs or counteract some Plk1-dependent modification. Per CCC's broad definition, any novel protein whose depletion or mutation leads to the formation of structurally unstable centrioles could be classified as "required for CCC". It will be important to start refining this classification by carefully dissecting the hierarchical incorporation of centriolar components in time and space and by meticulously characterizing ultrastructural defects that occur after removal or mutation of each protein.

Finally, the level of centriole maturation is inversely proportional to the ability of centrioles to elongate. Although all centrioles are exposed to the same cytoplasmic pool of centrosomal proteins, only immature centrioles elongate, while mature centrioles maintain their previously established length. This raises an attractive possibility that Plk1 plays a dual role during centriole assembly. Through association with multiple centriole elongation and maturation factors, Plk1 could couple these two opposing processes, establishing some control of the centriole size during unperturbed cell cycles.

\section{Posttranslational Modifications of Centriole Microtubules-What are They Good for?}

During their maturation, procentrioles additionally acquire posttranslational modifications. Centriolar $\alpha$ - and $\beta$-tubulins are heavily modified by acetylation, glutamylation, glycylation, and detyrosination [229-231]. In addition to centrioles and ciliary axonemes (Figure 5), acetylation is enriched on stabilized cytosolic MTs, with a predominant acetylation site on lysine 40 (K40) of $\alpha$-tubulin [232]. Acetylation sites other than K40 have been identified on $\alpha$ - and $\beta$-tubulins [233,234] which modulate the dynamics of MT nucleation and stability $[235,236]$. Mature human centrioles are heavily acetylated across the entire MT length (Figure 5). Recent analysis of procentriole acetylation by expansion microscopy showed that procentriole MTs are acetylated from their earliest stages (Figure 5B), with acetylated signal increasing gradually from proximal to distal procentriole ends from $\mathrm{S}^{1}$ phase until $\mathrm{G} 1^{2}$ [237]. By the time the procentrioles finish mitosis ${ }^{1}$, the entire length of MTs is acetylated, although the acetylation signal still shows a proximal-distal gradient until middle $\mathrm{G}^{2}$ (Figure 5C) [237].

Centrioles are also heavily glutamylated (Figure 5). Glutamylation occurs on $\alpha$ - and $\beta$-tubulin $C$-terminal tails that protrude above the MT lattice. Glutamate chains can be of various lengths and they regulate interactions between MT-interacting proteins, as well as the stability and function of microtubules [238,239]. Injection of a monoclonal antibody (GT335) specific to octapeptide EGEGE*EEG, with glutamate on the fifth $E$ residue, compromised centrosome integrity in mitosis [240]. So, glutamylation is widely considered to stabilize centrioles. However, while overexpression of deglutamylase CCP5 removed glutamylation detectable by GT335 antibodies, it did not destabilize centrioles or prevent their PCM recruitment [178]. On mammalian mature centrioles, an antibody recognizing a chain of $\geq 4$ glutamates, shows that the polyglutamylated signal does not occupy the entire centriole length and is more concentrated around the centriole's proximal ends (Figure 5C). This is consistent with the finding that the polyglutamylation signal is localized at the outer, $\mathrm{C}$ tubule of MT triplets [241], which is naturally missing from distal ends. Polyglutamylation signal is, in some cell types, detectable on procentrioles already in $\mathrm{S}^{1}$, but it remains of significantly lower intensity throughout the next cell cycle (Figure 5D), reaching the levels of mature centrioles sometimes only in mitosis ${ }^{2}$. In addition, the levels of polyglutamylated signal can be very different between two mother centrioles of the same cell (Figure 5E). This relatively late and unevenly distributed posttranslational modification would be more consistent with some functional role rather than a role in centriole stability. It has yet to be understood how posttranslational modifications of centrioles affect centriole structuring, stability, and function. 
A

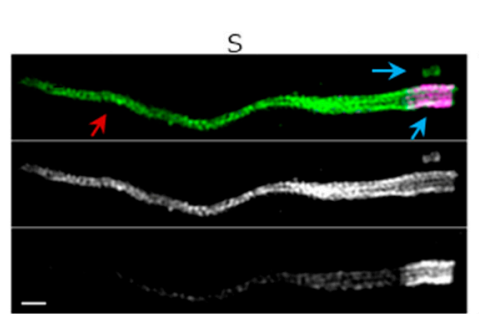

Acetylated tubulin

Polyglutamylation
B

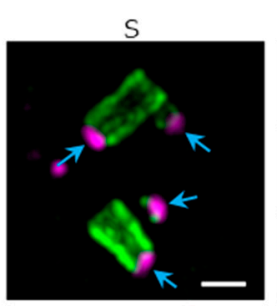

Acetylated tubulin Cep290
D

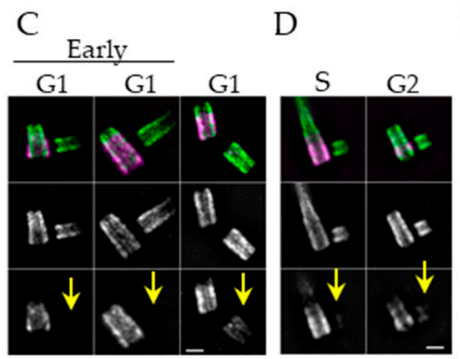

Acetylated tubulin

Polyglutamylation
E

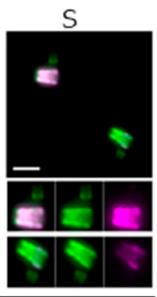

Q⿻

Figure 5. Acetylation and polyglutamylation of centrioles and cilia. Figure illustrates centrioles and basal bodies with cilia from cultured cells. Cells were expanded 4.2-fold (as detailed in Ref. [237]) and imaged by structured illumination microscopy (SIM, A-D) or conventional widefield microscope using $60 \times$ lens (E). Centrioles and cilia were co-immunolabeled with antibodies recognizing acetylated tubulin (Sigma; T7451) and centriole 'cap' protein Cep290 (Abcam; ab84870) or polyglutamylated tubulin (using an antibody which recognizes a chain of 4 or more glutamates, Adipogen (rabbit, AG-25B-0030-C050)). (A) Duplicated older mother centriole from mIMCD3 (mouse inner medullary collecting duct) cell associated with a cilium. Both centrioles (blue arrows) and the ciliary axoneme, (red arrows) are acetylated. Mother centriole and ciliary axoneme are also polyglutamylated. (B) Duplicated mother centrioles from HeLa cells associated with short procentrioles. Cep290 'caps' distal ends of centrioles (blue arrows). Note that very short procentrioles are already acetylated. (C) G1 centrioles from RPE-1 cells. Mother centrioles are acetylated along the entire MT length but polyglutamylation signal is not present on distal ends. Daughter centrioles still lack or have low levels of polyglutamylation in G1 (yellow arrows). (D) Examples of centrioles from mIMCD3 cells. Mother centrioles are acetylated and polyglutamylated. Polyglutamylation signal associated with procentrioles is low (yellow arrows). (E) Examples of two duplicated mother centrioles from a HeLa cell in S/G2 phase. One (older) mother centriole is more polyglutamylated than the younger mother centriole. Scale bars: $1000 \mathrm{~nm}$.

\section{Perspectives}

Anomalies in centrioles, centrosomes, and centrosomal proteins have been heavily researched in their connection to cancer and genetic disease [242-245]. In addition, recent findings identified centriolar structural and numerical defects as promoters of tumorigenesis and tumor invasion and are bringing the centriole and the centrosome to the limelight again. Although most centriolar ultrastructural features have been described by electron microscopy in the seventies and eighties of the last century, with so many components packed in such a small volume and interacting with each other in complex patterns, unraveling the centriole assembly process and the roles of individual centrosomal components is not an easy task. The accessibility of precise genetic tools and super resolution microscopy approaches are accelerating our understanding of centriole ultrastructure and our understanding of the relationship between centriolar structure and function. Many old unanswered questions can now be revisited and reanalyzed with a sophisticated set of tools. Although many concepts and a basic understanding of centriole assembly were established early on, the evolving precision of modern-day imaging and genetic tools promises exciting days ahead for centriole and centrosome researchers.

Author Contributions: All authors wrote the manuscript, C.S., and J.L. prepared illustrations. All authors have read and agree to the published version of the manuscript.

Funding: This research was supported by the Intramural Research Program of the National Institutes of Health (NIH), National Cancer Institute to J.L.

Acknowledgments: We thank Kimberly Lukasik and Meredith Metzger for helpful comments and editing.

Conflicts of Interest: The authors declare no conflict of interest. 


\section{References}

1. Arquint, C.; Gabryjonczyk, A.M.; Nigg, E.A. Centrosomes as signalling centres. Philos. Trans. R. Soc. Lond. Ser. B Biol. Sci. 2014, 369. [CrossRef] [PubMed]

2. Nigg, E.A.; Schnerch, D.; Ganier, O. Impact of Centrosome Aberrations on Chromosome Segregation and Tissue Architecture in Cancer. Cold Spring Harb. Symp. Quant. Biol. 2017, 82, 137-144. [CrossRef]

3. Vertii, A.; Hehnly, H.; Doxsey, S. The Centrosome, a Multitalented Renaissance Organelle. Cold Spring Harb. Perspect. Biol. 2016, 8. [CrossRef] [PubMed]

4. Wu, J.; Akhmanova, A. Microtubule-Organizing Centers. Annu Rev. Cell Dev. Biol. 2017, 33, 51-75. [CrossRef]

5. Nigg, E.A.; Holland, A.J. Once and only once: Mechanisms of centriole duplication and their deregulation in disease. Nat. Rev. Mol. Cell Biol. 2018, 19, 297-312. [CrossRef] [PubMed]

6. Roman, A.C.; Garrido-Jimenez, S.; Diaz-Chamorro, S.; Centeno, F.; Carvajal-Gonzalez, J.M. Centriole Positioning: Not Just a Little Dot in the Cell. Results Probl. Cell Differ. 2019, 67, 201-221. [CrossRef] [PubMed]

7. Anvarian, Z.; Mykytyn, K.; Mukhopadhyay, S.; Pedersen, L.B.; Christensen, S.T. Cellular signalling by primary cilia in development, organ function and disease. Nat. Rev. Nephrol. 2019, 15, 199-219. [CrossRef] [PubMed]

8. Mitchison, H.M.; Valente, E.M. Motile and non-motile cilia in human pathology: From function to phenotypes. J. Pathol. 2017, 241, 294-309. [CrossRef]

9. Nachury, M.V. How do cilia organize signalling cascades? Philos. Trans. R. Soc. Lond. Ser. BBiol. Sci. 2014, 369. [CrossRef]

10. Nishimura, Y.; Kasahara, K.; Shiromizu, T.; Watanabe, M.; Inagaki, M. Primary Cilia as Signaling Hubs in Health and Disease. Adv. Sci. (Weinh. Baden-Wurtt. Ger.) 2019, 6, 1801138. [CrossRef]

11. Chavali, P.L.; Putz, M.; Gergely, F. Small organelle, big responsibility: The role of centrosomes in development and disease. Philos. Trans. R. Soc. Lond. Ser. BBiol. Sci. 2014, 369. [CrossRef]

12. Nigg, E.A.; Cajanek, L.; Arquint, C. The centrosome duplication cycle in health and disease. FEBS Lett. 2014, 588, 2366-2372. [CrossRef] [PubMed]

13. Bornens, M.; Azimzadeh, J. Origin and evolution of the centrosome. Adv. Exp. Med. Biol. 2007, 607, 119-129. [CrossRef] [PubMed]

14. Carvalho-Santos, Z.; Azimzadeh, J.; Pereira-Leal, J.B.; Bettencourt-Dias, M. Evolution: Tracing the origins of centrioles, cilia, and flagella. J. Cell Biol. 2011, 194, 165-175. [CrossRef] [PubMed]

15. Azimzadeh, J.; Marshall, W.F. Building the centriole. Curr. Biol. 2010, 20, R816-R825. [CrossRef]

16. Gupta, A.; Kitagawa, D. Ultrastructural diversity between centrioles of eukaryotes. J. Biochem. 2018, 164, 1-8. [CrossRef]

17. Hodges, M.E.; Scheumann, N.; Wickstead, B.; Langdale, J.A.; Gull, K. Reconstructing the evolutionary history of the centriole from protein components. J. Cell Sci. 2010, 123, 1407-1413. [CrossRef]

18. Kong, D.; Loncarek, J. Correlative light and electron microscopy analysis of the centrosome: A step-by-step protocol. Methods Cell Biol. 2015, 129, 1-18. [CrossRef]

19. Bowler, M.; Kong, D.; Sun, S.; Nanjundappa, R.; Evans, L.; Farmer, V.; Holland, A.; Mahjoub, M.R.; Sui, H.; Loncarek, J. High-resolution characterization of centriole distal appendage morphology and dynamics by correlative STORM and electron microscopy. Nat. Commun. 2019, 10, 993. [CrossRef]

20. Vorobjev, I.A.; Yu, S.C. Centrioles in the cell cycle. I. Epithelial cells. J. Cell Biol. 1982, 93, 938-949. [CrossRef]

21. Anderson, R.G.; Brenner, R.M. The formation of basal bodies (centrioles) in the Rhesus monkey oviduct. J. Cell Biol. 1971, 50, 10-34. [CrossRef]

22. Woodruff, J.B.; Wueseke, O.; Hyman, A.A. Pericentriolar material structure and dynamics. Philos. Trans. R. Soc. Lond. Ser. BBiol. Sci. 2014, 369. [CrossRef]

23. Varadarajan, R.; Rusan, N.M. Bridging centrioles and PCM in proper space and time. Essays Biochem. 2018, 62, 793-801. [CrossRef] [PubMed]

24. Sonnen, K.F.; Schermelleh, L.; Leonhardt, H.; Nigg, E.A. 3D-structured illumination microscopy provides novel insight into architecture of human centrosomes. Biol. Open 2012, 1, 965-976. [CrossRef] [PubMed]

25. Lawo, S.; Hasegan, M.; Gupta, G.D.; Pelletier, L. Subdiffraction imaging of centrosomes reveals higher-order organizational features of pericentriolar material. Nat. Cell Biol. 2012, 14, 1148-1158. [CrossRef] [PubMed] 
26. Mennella, V.; Keszthelyi, B.; McDonald, K.L.; Chhun, B.; Kan, F.; Rogers, G.C.; Huang, B.; Agard, D.A. Subdiffraction-resolution fluorescence microscopy reveals a domain of the centrosome critical for pericentriolar material organization. Nat. Cell Biol. 2012, 14, 1159-1168. [CrossRef]

27. Wei, Z.; Kim, T.S.; Ahn, J.I.; Meng, L.; Chen, Y.; Ryu, E.K.; Ku, B.; Zhou, M.; Kim, S.J.; Bang, J.K.; et al. Requirement of the Cep57-Cep63 interaction for proper Cep152 recruitment and centriole duplication. Mol. Cell. Biol. 2020. [CrossRef]

28. Kim, T.S.; Zhang, L.; Il Ahn, J.; Meng, L.; Chen, Y.; Lee, E.; Bang, J.K.; Lim, J.M.; Ghirlando, R.; Fan, L.; et al. Molecular architecture of a cylindrical self-assembly at human centrosomes. Nat. Commun. 2019, $10,1151$. [CrossRef]

29. Fu, J.; Glover, D.M. Structured illumination of the interface between centriole and peri-centriolar material. Open Biol. 2012, 2, 120104. [CrossRef]

30. Joo, K.; Kim, C.G.; Lee, M.S.; Moon, H.Y.; Lee, S.H.; Kim, M.J.; Kweon, H.S.; Park, W.Y.; Kim, C.H.; Gleeson, J.G.; et al. CCDC41 is required for ciliary vesicle docking to the mother centriole. Proc. Natl. Acad. Sci. USA 2013, 110, 5987-5992. [CrossRef]

31. Tanos, B.E.; Yang, H.-J.; Soni, R.; Wang, W.-J.; Macaluso, F.P.; Asara, J.M.; Tsou, M.-F.B. Centriole distal appendages promote membrane docking, leading to cilia initiation. Genes Dev. 2013, 27, 163-168. [CrossRef]

32. Graser, S.; Stierhof, Y.-D.; Lavoie, S.B.; Gassner, O.S.; Lamla, S.; Le Clech, M.; Nigg, E.A. Cep164, a novel centriole appendage protein required for primary cilium formation. J. Cell Biol. 2007, 179, 321-330. [CrossRef]

33. Sillibourne, J.E.; Hurbain, I.; Grand-Perret, T.; Goud, B.; Tran, P.; Bornens, M. Primary ciliogenesis requires the distal appendage component Cep123. Biol. Open 2013, 2, 535-545. [CrossRef] [PubMed]

34. Ye, X.; Zeng, H.; Ning, G.; Reiter, J.F.; Liu, A. C2cd3 is critical for centriolar distal appendage assembly and ciliary vesicle docking in mammals. Proc. Natl. Acad. Sci. USA 2014, 111, 2164-2169. [CrossRef] [PubMed]

35. Uzbekov, R.; Alieva, I. Who are you, subdistal appendages of centriole? Open Biol. 2018, 8. [CrossRef] [PubMed]

36. Paintrand, M.; Moudjou, M.; Delacroix, H.; Bornens, M. Centrosome organization and centriole architecture: Their sensitivity to divalent cations. J. Struct. Biol. 1992, 108, 107-128. [CrossRef]

37. Pizon, V.; Gaudin, N.; Poteau, M.; Cifuentes-Diaz, C.; Demdou, R.; Heyer, V.; Reina San Martin, B.; Azimzadeh, J. hVFL3/CCDC61 is a component of mother centriole subdistal appendages required for centrosome cohesion and positioning. Biol. Cell 2020, 112, 22-37. [CrossRef]

38. Piel, M.; Meyer, P.; Khodjakov, A.; Rieder, C.L.; Bornens, M. The respective contributions of the mother and daughter centrioles to centrosome activity and behavior in vertebrate cells. J. Cell Biol. 2000, 149, 317-330. [CrossRef]

39. Mogensen, M.M.; Malik, A.; Piel, M.; Bouckson-Castaing, V.; Bornens, M. Microtubule minus-end anchorage at centrosomal and non-centrosomal sites: The role of ninein. J. Cell Sci. 2000, 113, 3013-3023.

40. Delgehyr, N.; Sillibourne, J.; Bornens, M. Microtubule nucleation and anchoring at the centrosome are independent processes linked by ninein function. J. Cell Sci. 2005, 118, 1565-1575. [CrossRef]

41. Panic, M.; Hata, S.; Neuner, A.; Schiebel, E. The centrosomal linker and microtubules provide dual levels of spatial coordination of centrosomes. PLoS Genet. 2015, 11, e1005243. [CrossRef]

42. Hata, S.; Pastor Peidro, A.; Panic, M.; Liu, P.; Atorino, E.; Funaya, C.; Jäkle, U.; Pereira, G.; Schiebel, E. The balance between KIFC3 and EG5 tetrameric kinesins controls the onset of mitotic spindle assembly. Nat. Cell Biol. 2019, 21, 1138-1151. [CrossRef]

43. Nogales-Cadenas, R.; Abascal, F.; Díez-Pérez, J.; Carazo, J.M.; Pascual-Montano, A. CentrosomeDB: A human centrosomal proteins database. Nucleic Acids Res. 2009, 37, D175-D180. [CrossRef] [PubMed]

44. Alves-Cruzeiro, J.M.d.C.; Nogales-Cadenas, R.; Pascual-Montano, A.D. CentrosomeDB: A new generation of the centrosomal proteins database for Human and Drosophila melanogaster. Nucleic Acids Res. 2014, 42, D430-D436. [CrossRef] [PubMed]

45. Bauer, M.; Cubizolles, F.; Schmidt, A.; Nigg, E.A. Quantitative analysis of human centrosome architecture by targeted proteomics and fluorescence imaging. EMBO J. 2016, 35, 2152-2166. [CrossRef] [PubMed]

46. Andersen, J.S.; Wilkinson, C.J.; Mayor, T.; Mortensen, P.; Nigg, E.A.; Mann, M. Proteomic characterization of the human centrosome by protein correlation profiling. Nature 2003, 426, 570-574. [CrossRef] [PubMed]

47. Jakobsen, L.; Vanselow, K.; Skogs, M.; Toyoda, Y.; Lundberg, E.; Poser, I.; Falkenby, L.G.; Bennetzen, M.; Westendorf, J.; Nigg, E.A.; et al. Novel asymmetrically localizing components of human centrosomes identified by complementary proteomics methods. EMBO J. 2011, 30, 1520-1535. [CrossRef] 
48. Quarantotti, V.; Chen, J.X.; Tischer, J.; Gonzalez Tejedo, C.; Papachristou, E.K.; D'Santos, C.S.; Kilmartin, J.V.; Miller, M.L.; Gergely, F. Centriolar satellites are acentriolar assemblies of centrosomal proteins. EMBO J. 2019, 38, e101082. [CrossRef]

49. Hossain, D.; Tsang, W.Y. The Role of Protein Acetylation in Centrosome Biology. Results Probl. Cell Differ. 2019, 67, 17-25. [CrossRef]

50. Fry, A.M.; Mayor, T.; Nigg, E.A. Regulating centrosomes by protein phosphorylation. Curr. Top. Dev. Biol. 2000, 49, 291-312. [CrossRef] [PubMed]

51. Habermann, K.; Lange, B.M. New insights into subcomplex assembly and modifications of centrosomal proteins. Cell Div. 2012, 7, 17. [CrossRef] [PubMed]

52. Santamaria, A.; Wang, B.; Elowe, S.; Malik, R.; Zhang, F.; Bauer, M.; Schmidt, A.; Sillje, H.H.; Korner, R.; Nigg, E.A. The Plk1-dependent phosphoproteome of the early mitotic spindle. Mol. Cell. Proteom.: MCP 2011, 10. [CrossRef]

53. Darling, S.; Fielding, A.B.; Sabat-Pospiech, D.; Prior, I.A.; Coulson, J.M. Regulation of the cell cycle and centrosome biology by deubiquitylases. Biochem. Soc. Trans. 2017, 45, 1125-1136. [CrossRef]

54. Balestra, F.R.; von Tobel, L.; Gonczy, P. Paternally contributed centrioles exhibit exceptional persistence in C. elegans embryos. Cell Res. 2015, 25, 642-644. [CrossRef] [PubMed]

55. Uzbekov, R.E. Centriole duplication in PE (SPEV) cells starts before the beginning of the DNA replication. Biochem. (Mosc.) Suppl. Ser. A Membr. Cell Biol. 2007, 1, 206-211. [CrossRef]

56. Robbins, E.; Jentzsch, G.; Micali, A. The centriole cycle in synchronized HeLa cells. J. Cell Biol. 1968, 36, 329-339. [CrossRef]

57. Tsou, M.F.; Stearns, T. Controlling centrosome number: Licenses and blocks. Curr. Opin. Cell Biol. 2006, 18, 74-78. [CrossRef] [PubMed]

58. Delattre, M.; Gonczy, P. The arithmetic of centrosome biogenesis. J. Cell Sci. 2004, 117, 1619-1630. [CrossRef] [PubMed]

59. Hinchcliffe, E.H.; Sluder, G. "It takes two to tango": Understanding how centrosome duplication is regulated throughout the cell cycle. Genes Dev. 2001, 15, 1167-1181. [CrossRef] [PubMed]

60. Hirono, M. Cartwheel assembly. Philos. Trans. R. Soc. Lond. Ser. BBiol. Sci. 2014, 369. [CrossRef]

61. Guichard, P.; Hamel, V.; Gonczy, P. The Rise of the Cartwheel: Seeding the Centriole Organelle. Bioessays News Rev. Mol. Cell. Dev. Biol. 2018, 40, e1700241. [CrossRef]

62. Gibbons, I.R.; Grimstone, A.V. On flagellar structure in certain flagellates. J. Biophys. Biochem. Cytol. 1960, 7 , 697-716. [CrossRef]

63. Carvalho-Santos, Z.; Machado, P.; Alvarez-Martins, I.; Gouveia, S.M.; Jana, S.C.; Duarte, P.; Amado, T.; Branco, P.; Freitas, M.C.; Silva, S.T.; et al. BLD10/CEP135 is a microtubule-associated protein that controls the formation of the flagellum central microtubule pair. Dev. Cell 2012, 23, 412-424. [CrossRef]

64. Roque, H.; Wainman, A.; Richens, J.; Kozyrska, K.; Franz, A.; Raff, J.W. Drosophila Cep135/Bld10 maintains proper centriole structure but is dispensable for cartwheel formation. J. Cell Sci. 2012, 125, 5881-5886. [CrossRef]

65. Mottier-Pavie, V.; Megraw, T.L. Drosophila bld10 is a centriolar protein that regulates centriole, basal body, and motile cilium assembly. Mol. Biol. Cell 2009, 20, 2605-2614. [CrossRef]

66. Matsuura, K.; Lefebvre, P.A.; Kamiya, R.; Hirono, M. Bld10p, a novel protein essential for basal body assembly in Chlamydomonas: Localization to the cartwheel, the first ninefold symmetrical structure appearing during assembly. J. Cell Biol. 2004, 165, 663-671. [CrossRef]

67. Hiraki, M.; Nakazawa, Y.; Kamiya, R.; Hirono, M. Bld10p constitutes the cartwheel-spoke tip and stabilizes the 9-fold symmetry of the centriole. Curr. Biol. 2007, 17, 1778-1783. [CrossRef]

68. Kleylein-Sohn, J.; Westendorf, J.; Le Clech, M.; Habedanck, R.; Stierhof, Y.D.; Nigg, E.A. Plk4-induced centriole biogenesis in human cells. Dev. Cell 2007, 13, 190-202. [CrossRef]

69. Leidel, S.; Delattre, M.; Cerutti, L.; Baumer, K.; Gonczy, P. SAS-6 defines a protein family required for centrosome duplication in C. elegans and in human cells. Nat. Cell Biol. 2005, 7, 115-125. [CrossRef]

70. Nakazawa, Y.; Hiraki, M.; Kamiya, R.; Hirono, M. SAS-6 is a cartwheel protein that establishes the 9-fold symmetry of the centriole. Curr. Biol. 2007, 17, 2169-2174. [CrossRef] [PubMed]

71. Hilbert, M.; Noga, A.; Frey, D.; Hamel, V.; Guichard, P.; Kraatz, S.H.; Pfreundschuh, M.; Hosner, S.; Fluckiger, I.; Jaussi, R.; et al. SAS-6 engineering reveals interdependence between cartwheel and microtubules in determining centriole architecture. Nat. Cell Biol. 2016, 18, 393-403. [CrossRef] [PubMed] 
72. Kong, D.; Sahabandu, N.; Sullenberger, C.; Vasquez-Limeta, A.; Luvsanjav, D.; Lukasik, K.; Loncarek, J. Prolonged mitosis results in structurally aberrant and over-elongated centrioles. J. Cell Biol. 2020, 219. [CrossRef] [PubMed]

73. Guichard, P.; Chretien, D.; Marco, S.; Tassin, A.M. Procentriole assembly revealed by cryo-electron tomography. EMBO J. 2010, 29, 1565-1572. [CrossRef]

74. Dippell, R.V. The development of basal bodies in paramecium. Proc. Natl. Acad. Sci. USA 1968, 61, 461-468. [CrossRef]

75. Li, S.; Fernandez, J.J.; Marshall, W.F.; Agard, D.A. Electron cryo-tomography provides insight into procentriole architecture and assembly mechanism. eLife 2019, 8. [CrossRef]

76. Guichard, P.; Hachet, V.; Majubu, N.; Neves, A.; Demurtas, D.; Olieric, N.; Fluckiger, I.; Yamada, A.; Kihara, K.; Nishida, Y.; et al. Native architecture of the centriole proximal region reveals features underlying its 9-fold radial symmetry. Curr. Biol. 2013, 23, 1620-1628. [CrossRef] [PubMed]

77. Li, S.; Fernandez, J.J.; Marshall, W.F.; Agard, D.A. Three-dimensional structure of basal body triplet revealed by electron cryo-tomography. EMBO J. 2012, 31, 552-562. [CrossRef] [PubMed]

78. Meehl, J.B.; Bayless, B.A.; Giddings, T.H., Jr.; Pearson, C.G.; Winey, M. Tetrahymena Poc1 ensures proper intertriplet microtubule linkages to maintain basal body integrity. Mol. Biol. Cell 2016, 27, 2394-2403. [CrossRef] [PubMed]

79. Anderson, R.G.W. The three-dimensional structure of the basal body from the Rhesus monkey oviduct. J. Cell Biol. 1972, 54, 246-265. [CrossRef]

80. Alvey, P.L. Do adult centrioles contain cartwheels and lie at right angles to each other? Cell Biol. Int. Rep. 1986, 10, 589-598. [CrossRef]

81. Habedanck, R.; Stierhof, Y.D.; Wilkinson, C.J.; Nigg, E.A. The Polo kinase Plk4 functions in centriole duplication. Nat. Cell Biol. 2005, 7, 1140-1146. [CrossRef]

82. Bettencourt-Dias, M.; Rodrigues-Martins, A.; Carpenter, L.; Riparbelli, M.; Lehmann, L.; Gatt, M.K.; Carmo, N.; Balloux, F.; Callaini, G.; Glover, D.M. SAK/PLK4 is required for centriole duplication and flagella development. Curr. Biol. 2005, 15, 2199-2207. [CrossRef]

83. O'Connell, K.F.; Caron, C.; Kopish, K.R.; Hurd, D.D.; Kemphues, K.J.; Li, Y.; White, J.G.; The, C. elegans zyg-1 gene encodes a regulator of centrosome duplication with distinct maternal and paternal roles in the embryo. Cell 2001, 105, 547-558. [CrossRef]

84. Vulprecht, J.; David, A.; Tibelius, A.; Castiel, A.; Konotop, G.; Liu, F.; Bestvater, F.; Raab, M.S.; Zentgraf, H.; Izraeli, S.; et al. STIL is required for centriole duplication in human cells. J. Cell Sci. 2012, 125, 1353-1362. [CrossRef]

85. Arquint, C.; Nigg, E.A. The PLK4-STIL-SAS-6 module at the core of centriole duplication. Biochem. Soc. Trans. 2016, 44, 1253-1263. [CrossRef]

86. Stevens, N.R.; Dobbelaere, J.; Brunk, K.; Franz, A.; Raff, J.W. Drosophila Ana2 is a conserved centriole duplication factor. J. Cell Biol. 2010, 188, 313-323. [CrossRef]

87. Dobbelaere, J.; Josue, F.; Suijkerbuijk, S.; Baum, B.; Tapon, N.; Raff, J. A genome-wide RNAi screen to dissect centriole duplication and centrosome maturation in Drosophila. PLoS Biol. 2008, 6, e224. [CrossRef] [PubMed]

88. Goshima, G.; Wollman, R.; Goodwin, S.S.; Zhang, N.; Scholey, J.M.; Vale, R.D.; Stuurman, N. Genes required for mitotic spindle assembly in Drosophila S2 cells. Science 2007, 316, 417-421. [CrossRef] [PubMed]

89. Delattre, M.; Leidel, S.; Wani, K.; Baumer, K.; Bamat, J.; Schnabel, H.; Feichtinger, R.; Schnabel, R.; Gonczy, P. Centriolar SAS-5 is required for centrosome duplication in C. elegans. Nat. Cell Biol. 2004, 6, 656-664. [CrossRef]

90. Arquint, C.; Nigg, E.A. STIL microcephaly mutations interfere with APC/C-mediated degradation and cause centriole amplification. Curr. Biol. 2014, 24, 351-360. [CrossRef] [PubMed]

91. Tang, C.J.; Lin, S.Y.; Hsu, W.B.; Lin, Y.N.; Wu, C.T.; Lin, Y.C.; Chang, C.W.; Wu, K.S.; Tang, T.K. The human microcephaly protein STIL interacts with CPAP and is required for procentriole formation. EMBO J. 2011, 30, 4790-4804. [CrossRef]

92. Rogers, G.C.; Rusan, N.M.; Roberts, D.M.; Peifer, M.; Rogers, S.L. The SCF Slimb ubiquitin ligase regulates Plk4/Sak levels to block centriole reduplication. J. Cell Biol. 2009, 184, 225-239. [CrossRef] 
93. Sillibourne, J.E.; Tack, F.; Vloemans, N.; Boeckx, A.; Thambirajah, S.; Bonnet, P.; Ramaekers, F.C.; Bornens, M.; Grand-Perret, T. Autophosphorylation of polo-like kinase 4 and its role in centriole duplication. Mol. Biol. Cell 2010, 21, 547-561. [CrossRef]

94. Holland, A.J.; Lan, W.; Cleveland, D.W. Centriole duplication: A lesson in self-control. Cell Cycle 2010, 9, 2731-2736. [CrossRef]

95. Holland, A.J.; Lan, W.; Niessen, S.; Hoover, H.; Cleveland, D.W. Polo-like kinase 4 kinase activity limits centrosome overduplication by autoregulating its own stability. J. Cell Biol. 2010, 188, 191-198. [CrossRef]

96. Cunha-Ferreira, I.; Rodrigues-Martins, A.; Bento, I.; Riparbelli, M.; Zhang, W.; Laue, E.; Callaini, G.; Glover, D.M.; Bettencourt-Dias, M. The SCF/Slimb ubiquitin ligase limits centrosome amplification through degradation of SAK/PLK4. Curr. Biol. 2009, 19, 43-49. [CrossRef]

97. Guderian, G.; Westendorf, J.; Uldschmid, A.; Nigg, E.A. Plk4 trans-autophosphorylation regulates centriole number by controlling betaTrCP-mediated degradation. J. Cell Sci. 2010, 123, 2163-2169. [CrossRef] [PubMed]

98. Lopes, C.A.; Jana, S.C.; Cunha-Ferreira, I.; Zitouni, S.; Bento, I.; Duarte, P.; Gilberto, S.; Freixo, F.; Guerrero, A.; Francia, M.; et al. PLK4 trans-Autoactivation Controls Centriole Biogenesis in Space. Dev. Cell 2015, 35, 222-235. [CrossRef] [PubMed]

99. Brown, N.J.; Marjanovic, M.; Luders, J.; Stracker, T.H.; Costanzo, V. Cep63 and cep152 cooperate to ensure centriole duplication. PLoS ONE 2013, 8, e69986. [CrossRef]

100. Cizmecioglu, O.; Arnold, M.; Bahtz, R.; Settele, F.; Ehret, L.; Haselmann-Weiss, U.; Antony, C.; Hoffmann, I. Cep152 acts as a scaffold for recruitment of Plk4 and CPAP to the centrosome. J. Cell Biol. 2010, 191, 731-739. [CrossRef]

101. Sonnen, K.F.; Gabryjonczyk, A.M.; Anselm, E.; Stierhof, Y.D.; Nigg, E.A. Human Cep192 and Cep152 cooperate in Plk4 recruitment and centriole duplication. J. Cell Sci. 2013, 126, 3223-3233. [CrossRef]

102. Park, S.Y.; Park, J.E.; Kim, T.S.; Kim, J.H.; Kwak, M.J.; Ku, B.; Tian, L.; Murugan, R.N.; Ahn, M.; Komiya, S.; et al. Molecular basis for unidirectional scaffold switching of human Plk4 in centriole biogenesis. Nat. Struct. Mol. Biol. 2014, 21, 696-703. [CrossRef]

103. Kim, T.S.; Park, J.E.; Shukla, A.; Choi, S.; Murugan, R.N.; Lee, J.H.; Ahn, M.; Rhee, K.; Bang, J.K.; Kim, B.Y.; et al. Hierarchical recruitment of Plk4 and regulation of centriole biogenesis by two centrosomal scaffolds, Cep192 and Cep152. Proc. Natl. Acad. Sci. USA 2013, 110, E4849-E4857. [CrossRef]

104. McLamarrah, T.A.; Buster, D.W.; Galletta, B.J.; Boese, C.J.; Ryniawec, J.M.; Hollingsworth, N.A.; Byrnes, A.E.; Brownlee, C.W.; Slep, K.C.; Rusan, N.M.; et al. An ordered pattern of Ana2 phosphorylation by Plk4 is required for centriole assembly. J. Cell Biol. 2018, 217, 1217-1231. [CrossRef]

105. Ohta, M.; Ashikawa, T.; Nozaki, Y.; Kozuka-Hata, H.; Goto, H.; Inagaki, M.; Oyama, M.; Kitagawa, D. Direct interaction of Plk4 with STIL ensures formation of a single procentriole per parental centriole. Nat. Commun. 2014, 5, 5267. [CrossRef]

106. Moyer, T.C.; Clutario, K.M.; Lambrus, B.G.; Daggubati, V.; Holland, A.J. Binding of STIL to Plk4 activates kinase activity to promote centriole assembly. J. Cell Biol. 2015, 209, 863-878. [CrossRef] [PubMed]

107. Kratz, A.S.; Barenz, F.; Richter, K.T.; Hoffmann, I. Plk4-dependent phosphorylation of STIL is required for centriole duplication. Biol. Open 2015, 4, 370-377. [CrossRef] [PubMed]

108. Dzhindzhev, N.S.; Tzolovsky, G.; Lipinszki, Z.; Abdelaziz, M.; Debski, J.; Dadlez, M.; Glover, D.M. Two-step phosphorylation of Ana2 by Plk4 is required for the sequential loading of Ana2 and Sas 6 to initiate procentriole formation. Open Biol. 2017, 7. [CrossRef] [PubMed]

109. Takao, D.; Yamamoto, S.; Kitagawa, D. A theory of centriole duplication based on self-organized spatial pattern formation. J. Cell Biol. 2019, 218, 3537-3547. [CrossRef] [PubMed]

110. Leda, M.; Holland, A.J.; Goryachev, A.B. Autoamplification and Competition Drive Symmetry Breaking: Initiation of Centriole Duplication by the PLK4-STIL Network. iScience 2018, 8, 222-235. [CrossRef] [PubMed]

111. Yamamoto, S.; Kitagawa, D. Self-organization of Plk4 regulates symmetry breaking in centriole duplication. Nat. Commun. 2019, 10, 1810. [CrossRef]

112. Gonczy, P.; Hatzopoulos, G.N. Centriole assembly at a glance. J. Cell Sci. 2019, 132. [CrossRef]

113. Dzhindzhev, N.S.; Tzolovsky, G.; Lipinszki, Z.; Schneider, S.; Lattao, R.; Fu, J.; Debski, J.; Dadlez, M.; Glover, D.M. Plk4 phosphorylates Ana2 to trigger Sas6 recruitment and procentriole formation. Curr. Biol. 2014, 24, 2526-2532. [CrossRef] 
114. Kitagawa, D.; Vakonakis, I.; Olieric, N.; Hilbert, M.; Keller, D.; Olieric, V.; Bortfeld, M.; Erat, M.C.; Fluckiger, I.; Gonczy, P.; et al. Structural basis of the 9-fold symmetry of centrioles. Cell 2011, 144, 364-375. [CrossRef]

115. Cottee, M.A.; Muschalik, N.; Johnson, S.; Leveson, J.; Raff, J.W.; Lea, S.M. The homo-oligomerisation of both Sas-6 and Ana2 is required for efficient centriole assembly in flies. eLife 2015, 4, e07236. [CrossRef]

116. Moyer, T.C.; Holland, A.J. PLK4 promotes centriole duplication by phosphorylating STIL to link the procentriole cartwheel to the microtubule wall. eLife 2019, 8. [CrossRef]

117. Kochanski, R.S.; Borisy, G.G. Mode of centriole duplication and distribution. J. Cell Biol. 1990, 110, $1599-1605$. [CrossRef] [PubMed]

118. Pearson, C.G.; Giddings, T.H., Jr.; Winey, M. Basal body components exhibit differential protein dynamics during nascent basal body assembly. Mol. Biol. Cell 2009, 20, 904-914. [CrossRef]

119. Chretien, D.; Buendia, B.; Fuller, S.D.; Karsenti, E. Reconstruction of the centrosome cycle from cryoelectron micrographs. J. Struct. Biol. 1997, 120, 117-133. [CrossRef]

120. Kuriyama, R.; Borisy, G.G. Centriole cycle in Chinese hamster ovary cells as determined by whole-mount electron microscopy. J. Cell Biol. 1981, 91, 814-821. [CrossRef]

121. Kohlmaier, G.; Loncarek, J.; Meng, X.; McEwen, B.F.; Mogensen, M.M.; Spektor, A.; Dynlacht, B.D.; Khodjakov, A.; Gonczy, P. Overly long centrioles and defective cell division upon excess of the SAS-4-related protein CPAP. Curr. Biol. 2009, 19, 1012-1018. [CrossRef]

122. Schmidt, T.I.; Kleylein-Sohn, J.; Westendorf, J.; Le Clech, M.; Lavoie, S.B.; Stierhof, Y.D.; Nigg, E.A. Control of centriole length by CPAP and CP110. Curr. Biol. 2009, 19, 1005-1011. [CrossRef]

123. Tang, C.J.; Fu, R.H.; Wu, K.S.; Hsu, W.B.; Tang, T.K. CPAP is a cell-cycle regulated protein that controls centriole length. Nat. Cell Biol. 2009, 11, 825-831. [CrossRef]

124. Pelletier, L.; O’Toole, E.; Schwager, A.; Hyman, A.A.; Muller-Reichert, T. Centriole assembly in Caenorhabditis elegans. Nature 2006, 444, 619-623. [CrossRef]

125. Zheng, X.; Gooi, L.M.; Wason, A.; Gabriel, E.; Mehrjardi, N.Z.; Yang, Q.; Zhang, X.; Debec, A.; Basiri, M.L.; Avidor-Reiss, T.; et al. Conserved TCP domain of Sas-4/CPAP is essential for pericentriolar material tethering during centrosome biogenesis. Proc. Natl. Acad. Sci. USA 2014, 111, E354-E363. [CrossRef]

126. Gopalakrishnan, J.; Mennella, V.; Blachon, S.; Zhai, B.; Smith, A.H.; Megraw, T.L.; Nicastro, D.; Gygi, S.P.; Agard, D.A.; Avidor-Reiss, T. Author Correction: Sas-4 provides a scaffold for cytoplasmic complexes and tethers them in a centrosome. Nat. Commun. 2020, 11, 1862. [CrossRef]

127. Comartin, D.; Gupta, G.D.; Fussner, E.; Coyaud, É.; Hasegan, M.; Archinti, M.; Cheung, S.W.T.; Pinchev, D.; Lawo, S.; Raught, B.; et al. CEP120 and SPICE1 Cooperate with CPAP in Centriole Elongation. Curr. Biol. 2013, 23, 1360-1366. [CrossRef]

128. Lin, Y.C.; Chang, C.W.; Hsu, W.B.; Tang, C.J.; Lin, Y.N.; Chou, E.J.; Wu, C.T.; Tang, T.K. Human microcephaly protein CEP135 binds to hSAS-6 and CPAP, and is required for centriole assembly. EMBO J. 2013, 32, 1141-1154. [CrossRef]

129. Lin, Y.N.; Wu, C.T.; Lin, Y.C.; Hsu, W.B.; Tang, C.J.; Chang, C.W.; Tang, T.K. CEP120 interacts with CPAP and positively regulates centriole elongation. J. Cell Biol. 2013, 202, 211-219. [CrossRef]

130. Gudi, R.; Haycraft, C.J.; Bell, P.D.; Li, Z.; Vasu, C. Centrobin-mediated regulation of the centrosomal protein 4.1-associated protein (CPAP) level limits centriole length during elongation stage. J. Biol. Chem. 2015, 290, 6890-6902. [CrossRef]

131. Sharma, A.; Aher, A.; Dynes, N.J.; Frey, D.; Katrukha, E.A.; Jaussi, R.; Grigoriev, I.; Croisier, M.; Kammerer, R.A.; Akhmanova, A.; et al. Centriolar CPAP/SAS-4 Imparts Slow Processive Microtubule Growth. Dev. Cell 2016, 37, 362-376. [CrossRef]

132. Zheng, X.; Ramani, A.; Soni, K.; Gottardo, M.; Zheng, S.; Ming Gooi, L.; Li, W.; Feng, S.; Mariappan, A.; Wason, A.; et al. Molecular basis for CPAP-tubulin interaction in controlling centriolar and ciliary length. Nat. Commun. 2016, 7, 11874. [CrossRef]

133. Hung, L.Y.; Chen, H.L.; Chang, C.W.; Li, B.R.; Tang, T.K. Identification of a novel microtubule-destabilizing motif in CPAP that binds to tubulin heterodimers and inhibits microtubule assembly. Mol. Biol. Cell 2004, 15, 2697-2706. [CrossRef]

134. Spektor, A.; Tsang, W.Y.; Khoo, D.; Dynlacht, B.D. Cep97 and CP110 Suppress a Cilia Assembly Program. Cell 2007, 130, 678-690. [CrossRef]

135. Franz, A.; Roque, H.; Saurya, S.; Dobbelaere, J.; Raff, J.W. CP110 exhibits novel regulatory activities during centriole assembly in Drosophila. J. Cell Biol. 2013, 203, 785-799. [CrossRef] 
136. Singla, V.; Romaguera-Ros, M.; Garcia-Verdugo, J.M.; Reiter, J.F. Ofd1, a human disease gene, regulates the length and distal structure of centrioles. Dev. Cell 2010, 18, 410-424. [CrossRef]

137. Chen, H.Y.; Wu, C.T.; Tang, C.C.; Lin, Y.N.; Wang, W.J.; Tang, T.K. Human microcephaly protein RTTN interacts with STIL and is required to build full-length centrioles. Nat. Commun. 2017, 8, 247. [CrossRef]

138. Stevens, N.R.; Dobbelaere, J.; Wainman, A.; Gergely, F.; Raff, J.W. Ana3 is a conserved protein required for the structural integrity of centrioles and basal bodies. J. Cell Biol. 2009, 187, 355-363. [CrossRef]

139. Fong, C.S.; Ozaki, K.; Tsou, M.B. PPP1R35 ensures centriole homeostasis by promoting centriole-to-centrosome conversion. Mol. Biol. Cell 2018, 29, 2801-2808. [CrossRef]

140. Sydor, A.M.; Coyaud, E.; Rovelli, C.; Laurent, E.; Liu, H.; Raught, B.; Mennella, V. PPP1R35 is a novel centrosomal protein that regulates centriole length in concert with the microcephaly protein RTTN. eLife 2018, 7. [CrossRef]

141. Chang, C.-W.; Hsu, W.-B.; Tsai, J.-J.; Tang, C.-J.C.; Tang, T.K. CEP295 interacts with microtubules and is required for centriole elongation. J. Cell Sci. 2016, 129, 2501-2513. [CrossRef] [PubMed]

142. Azimzadeh, J.; Hergert, P.; Delouvée, A.; Euteneuer, U.; Formstecher, E.; Khodjakov, A.; Bornens, M. hPOC5 is a centrin-binding protein required for assembly of full-length centrioles. J. Cell Biol. 2009, 185, 101-114. [CrossRef]

143. Tsai, J.J.; Hsu, W.B.; Liu, J.H.; Chang, C.W.; Tang, T.K. CEP120 interacts with C2CD3 and Talpid3 and is required for centriole appendage assembly and ciliogenesis. Sci. Rep. 2019, 9, 6037. [CrossRef]

144. Thauvin-Robinet, C.; Lee, J.S.; Lopez, E.; Herranz-Perez, V.; Shida, T.; Franco, B.; Jego, L.; Ye, F.; Pasquier, L.; Loget, P.; et al. The oral-facial-digital syndrome gene C2CD3 encodes a positive regulator of centriole elongation. Nat. Genet. 2014, 46, 905-911. [CrossRef]

145. Aydogan, M.G.; Wainman, A.; Saurya, S.; Steinacker, T.L.; Caballe, A.; Novak, Z.A.; Baumbach, J.; Muschalik, N.; Raff, J.W. A homeostatic clock sets daughter centriole size in flies. J. Cell Biol. 2018, 217, 1233-1248. [CrossRef]

146. Chang, J.; Cizmecioglu, O.; Hoffmann, I.; Rhee, K. PLK2 phosphorylation is critical for CPAP function in procentriole formation during the centrosome cycle. EMBO J. 2010, 29, 2395-2406. [CrossRef]

147. Golsteyn, R.M.; Mundt, K.E.; Fry, A.M.; Nigg, E.A. Cell cycle regulation of the activity and subcellular localization of Plk1, a human protein kinase implicated in mitotic spindle function. J. Cell Biol. 1995, 129, 1617-1628. [CrossRef]

148. Haren, L.; Stearns, T.; Luders, J. Plk1-dependent recruitment of gamma-tubulin complexes to mitotic centrosomes involves multiple PCM components. PLoS ONE 2009, 4, e5976. [CrossRef]

149. Lee, K.; Rhee, K. PLK1 phosphorylation of pericentrin initiates centrosome maturation at the onset of mitosis. J. Cell Biol. 2011, 195, 1093-1101. [CrossRef]

150. Joukov, V.; Walter, J.C.; De Nicolo, A. The Cep192-organized aurora A-Plk1 cascade is essential for centrosome cycle and bipolar spindle assembly. Mol. Cell 2014, 55, 578-591. [CrossRef] [PubMed]

151. Lane, H.A.; Nigg, E.A. Antibody microinjection reveals an essential role for human polo-like kinase 1 (Plk1) in the functional maturation of mitotic centrosomes. J. Cell Biol. 1996, 135, 1701-1713. [CrossRef] [PubMed]

152. Firat-Karalar, E.N.; Rauniyar, N.; Yates, J.R., 3rd; Stearns, T. Proximity interactions among centrosome components identify regulators of centriole duplication. Curr. Biol. 2014, 24, 664-670. [CrossRef]

153. Ma, S.; Charron, J.; Erikson, R.L. Role of Plk2 (Snk) in mouse development and cell proliferation. Mol. Cell. Biol. 2003, 23, 6936-6943. [CrossRef]

154. Wong, C.; Stearns, T. Centrosome number is controlled by a centrosome-intrinsic block to reduplication. Nat. Cell Biol. 2003, 5, 539-544. [CrossRef]

155. Loncarek, J.; Hergert, P.; Magidson, V.; Khodjakov, A. Control of daughter centriole formation by the pericentriolar material. Nat. Cell Biol. 2008, 10, 322-328. [CrossRef]

156. Kim, M.; O’Rourke, B.P.; Soni, R.K.; Jallepalli, P.V.; Hendrickson, R.C.; Tsou, M.F. Promotion and Suppression of Centriole Duplication Are Catalytically Coupled through PLK4 to Ensure Centriole Homeostasis. Cell Rep. 2016, 16, 1195-1203. [CrossRef]

157. Shukla, A.; Kong, D.; Sharma, M.; Magidson, V.; Loncarek, J. Plk1 relieves centriole block to reduplication by promoting daughter centriole maturation. Nat. Commun. 2015, 6, 8077. [CrossRef]

158. Seo, M.Y.; Jang, W.; Rhee, K. Integrity of the Pericentriolar Material Is Essential for Maintaining Centriole Association during M Phase. PLoS ONE 2015, 10, e0138905. [CrossRef] 
159. Tsou, M.F.; Wang, W.J.; George, K.A.; Uryu, K.; Stearns, T.; Jallepalli, P.V. Polo kinase and separase regulate the mitotic licensing of centriole duplication in human cells. Dev. Cell 2009, 17, 344-354. [CrossRef]

160. Kim, J.; Lee, K.; Rhee, K. PLK1 regulation of PCNT cleavage ensures fidelity of centriole separation during mitotic exit. Nat. Commun. 2015, 6, 10076. [CrossRef] [PubMed]

161. Matsuo, K.; Ohsumi, K.; Iwabuchi, M.; Kawamata, T.; Ono, Y.; Takahashi, M. Kendrin is a novel substrate for separase involved in the licensing of centriole duplication. Curr. Biol. 2012, 22, 915-921. [CrossRef] [PubMed]

162. Lee, K.; Rhee, K. Separase-dependent cleavage of pericentrin B is necessary and sufficient for centriole disengagement during mitosis. Cell Cycle 2012, 11, 2476-2485. [CrossRef]

163. Cabral, G.; Sans, S.S.; Cowan, C.R.; Dammermann, A. Multiple mechanisms contribute to centriole separation in C. elegans. Curr. Biol. 2013, 23, 1380-1387. [CrossRef]

164. Schöckel, L.; Möckel, M.; Mayer, B.; Boos, D.; Stemmann, O. Cleavage of cohesin rings coordinates the separation of centrioles and chromatids. Nat. Cell Biol. 2011, 13, 966-972. [CrossRef]

165. Oliveira, R.A.; Nasmyth, K. Cohesin cleavage is insufficient for centriole disengagement in Drosophila. Curr. Biol. 2013, 23, R601-R603. [CrossRef]

166. Wang, W.J.; Soni, R.K.; Uryu, K.; Tsou, M.F. The conversion of centrioles to centrosomes: Essential coupling of duplication with segregation. J. Cell Biol. 2011, 193, 727-739. [CrossRef]

167. Rieder, C.L.; Borisy, G.G. The centrosome cycle in PtK2 cells: Asymmetric distribution and structural changes in the pericentriolar material. Biol. Cell 1982, 44, 117-132.

168. Saurya, S.; Roque, H.; Novak, Z.A.; Wainman, A.; Aydogan, M.G.; Volanakis, A.; Sieber, B.; Pinto, D.M.; Raff, J.W. Drosophila Ana1 is required for centrosome assembly and centriole elongation. J. Cell Sci. 2016, 129, 2514-2525. [CrossRef] [PubMed]

169. Fu, J.; Lipinszki, Z.; Rangone, H.; Min, M.; Mykura, C.; Chao-Chu, J.; Schneider, S.; Dzhindzhev, N.S.; Gottardo, M.; Riparbelli, M.G.; et al. Conserved molecular interactions in centriole-to-centrosome conversion. Nat. Cell Biol. 2016, 18, 87-99. [CrossRef] [PubMed]

170. Tsuchiya, Y.; Yoshiba, S.; Gupta, A.; Watanabe, K.; Kitagawa, D. Cep295 is a conserved scaffold protein required for generation of a bona fide mother centriole. Nat. Commun. 2016, 7, 12567. [CrossRef] [PubMed]

171. Gomez-Ferreria, M.A.; Rath, U.; Buster, D.W.; Chanda, S.K.; Caldwell, J.S.; Rines, D.R.; Sharp, D.J. Human Cep192 is required for mitotic centrosome and spindle assembly. Curr. Biol. 2007, 17, 1960-1966. [CrossRef]

172. Joukov, V.; De Nicolo, A.; Rodriguez, A.; Walter, J.C.; Livingston, D.M. Centrosomal protein of 192 kDa (Cep192) promotes centrosome-driven spindle assembly by engaging in organelle-specific Aurora A activation. Proc. Natl. Acad. Sci. USA 2010, 107, 21022-21027. [CrossRef]

173. O'Rourke, B.P.; Gomez-Ferreria, M.A.; Berk, R.H.; Hackl, A.M.; Nicholas, M.P.; O’Rourke, S.C.; Pelletier, L.; Sharp, D.J. Cep192 controls the balance of centrosome and non-centrosomal microtubules during interphase. PLoS ONE 2014, 9, e101001. [CrossRef] [PubMed]

174. Conduit, P.T.; Richens, J.H.; Wainman, A.; Holder, J.; Vicente, C.C.; Pratt, M.B.; Dix, C.I.; Novak, Z.A.; Dobbie, I.M.; Schermelleh, L.; et al. A molecular mechanism of mitotic centrosome assembly in Drosophila. eLife 2014, 3, e03399. [CrossRef]

175. Novak, Z.A.; Conduit, P.T.; Wainman, A.; Raff, J.W. Asterless licenses daughter centrioles to duplicate for the first time in Drosophila embryos. Curr. Biol. 2014, 24, 1276-1282. [CrossRef]

176. Izquierdo, D.; Wang, W.J.; Uryu, K.; Tsou, M.F. Stabilization of cartwheel-less centrioles for duplication requires CEP295-mediated centriole-to-centrosome conversion. Cell Rep. 2014, 8, 957-965. [CrossRef]

177. Le Guennec, M.; Klena, N.; Gambarotto, D.; Laporte, M.H.; Tassin, A.M.; van den Hoek, H.; Erdmann, P.S.; Schaffer, M.; Kovacik, L.; Borgers, S.; et al. A helical inner scaffold provides a structural basis for centriole cohesion. Sci. Adv. 2020, 6, eaaz4137. [CrossRef]

178. Atorino, E.S.; Hata, S.; Funaya, C.; Neuner, A.; Schiebel, E. CEP44 ensures the formation of bona fide centriole wall, a requirement for the centriole-to-centrosome conversion. Nat. Commun. 2020, 11, 903. [CrossRef] [PubMed]

179. Venoux, M.; Tait, X.; Hames, R.S.; Straatman, K.R.; Woodland, H.R.; Fry, A.M. Poc1A and Poc1B act together in human cells to ensure centriole integrity. J. Cell Sci. 2013, 126, 163-175. [CrossRef]

180. Bayless, B.A.; Giddings, T.H., Jr.; Winey, M.; Pearson, C.G. Bld10/Cep135 stabilizes basal bodies to resist cilia-generated forces. Mol. Biol. Cell 2012, 23, 4820-4832. [CrossRef] 
181. Jerka-Dziadosz, M.; Gogendeau, D.; Klotz, C.; Cohen, J.; Beisson, J.; Koll, F. Basal body duplication in Paramecium: The key role of Bld10 in assembly and stability of the cartwheel. Cytoskelet. (HobokenN.J.) 2010, 67, 161-171. [CrossRef] [PubMed]

182. Sugioka, K.; Hamill, D.R.; Lowry, J.B.; McNeely, M.E.; Enrick, M.; Richter, A.C.; Kiebler, L.E.; Priess, J.R.; Bowerman, B. Centriolar SAS-7 acts upstream of SPD-2 to regulate centriole assembly and pericentriolar material formation. eLife 2017, 6. [CrossRef] [PubMed]

183. Wang, J.T.; Kong, D.; Hoerner, C.R.; Loncarek, J.; Stearns, T. Centriole triplet microtubules are required for stable centriole formation and inheritance in human cells. eLife 2017, 6. [CrossRef]

184. Remo, A.; Li, X.; Schiebel, E.; Pancione, M. The Centrosome Linker and Its Role in Cancer and Genetic Disorders. Trends Mol. Med. 2020, 26, 380-393. [CrossRef]

185. Vlijm, R.; Li, X.; Panic, M.; Ruthnick, D.; Hata, S.; Herrmannsdorfer, F.; Kuner, T.; Heilemann, M.; Engelhardt, J.; Hell, S.W.; et al. STED nanoscopy of the centrosome linker reveals a CEP68-organized, periodic rootletin network anchored to a C-Nap1 ring at centrioles. Proc. Natl. Acad. Sci. USA 2018, 115, E2246-E2253. [CrossRef]

186. Yang, J.; Adamian, M.; Li, T. Rootletin interacts with C-Nap1 and may function as a physical linker between the pair of centrioles/basal bodies in cells. Mol. Biol. Cell 2006, 17, 1033-1040. [CrossRef]

187. He, R.; Huang, N.; Bao, Y.; Zhou, H.; Teng, J.; Chen, J. LRRC45 is a centrosome linker component required for centrosome cohesion. Cell Rep. 2013, 4, 1100-1107. [CrossRef]

188. Yin, H.; Zheng, L.; Liu, W.; Zhang, D.; Li, W.; Yuan, L. Rootletin prevents Cep68 from VHL-mediated proteasomal degradation to maintain centrosome cohesion. Biochim. Biophys. Acta Mol. Cell Res. 2017, 1864, 645-654. [CrossRef]

189. Floriot, S.; Vesque, C.; Rodriguez, S.; Bourgain-Guglielmetti, F.; Karaiskou, A.; Gautier, M.; Duchesne, A.; Barbey, S.; Fritz, S.; Vasilescu, A.; et al. C-Nap1 mutation affects centriole cohesion and is associated with a Seckel-like syndrome in cattle. Nat. Commun. 2015, 6, 6894. [CrossRef]

190. Khateb, S.; Zelinger, L.; Mizrahi-Meissonnier, L.; Ayuso, C.; Koenekoop, R.K.; Laxer, U.; Gross, M.; Banin, E.; Sharon, D. A homozygous nonsense CEP250 mutation combined with a heterozygous nonsense C2orf71 mutation is associated with atypical Usher syndrome. J. Med. Genet. 2014, 51, 460-469. [CrossRef]

191. Remo, A.; Manfrin, E.; Parcesepe, P.; Ferrarini, A.; Han, H.S.; Mickys, U.; Laudanna, C.; Simbolo, M.; Malanga, D.; Oliveira, D.M.; et al. Centrosome Linker-induced Tetraploid Segregation Errors Link Rhabdoid Phenotypes and Lethal Colorectal Cancers. Mol. Cancer Res. 2018, 16, 1385-1395. [CrossRef]

192. Hatch, E.M.; Kulukian, A.; Holland, A.J.; Cleveland, D.W.; Stearns, T. Cep152 interacts with Plk4 and is required for centriole duplication. J. Cell Biol. 2010, 191, 721-729. [CrossRef]

193. Lukinavicius, G.; Lavogina, D.; Orpinell, M.; Umezawa, K.; Reymond, L.; Garin, N.; Gonczy, P.; Johnsson, K. Selective chemical crosslinking reveals a Cep57-Cep63-Cep152 centrosomal complex. Curr. Biol. 2013, 23, 265-270. [CrossRef]

194. Watanabe, K.; Takao, D.; Ito, K.K.; Takahashi, M.; Kitagawa, D. The Cep57-pericentrin module organizes PCM expansion and centriole engagement. Nat. Commun. 2019, 10, 931. [CrossRef]

195. Sir, J.H.; Barr, A.R.; Nicholas, A.K.; Carvalho, O.P.; Khurshid, M.; Sossick, A.; Reichelt, S.; D'Santos, C.; Woods, C.G.; Gergely, F. A primary microcephaly protein complex forms a ring around parental centrioles. Nat. Genet. 2011, 43, 1147-1153. [CrossRef]

196. Kuriyama, R.; Borisy, G.G. Microtubule-nucleating activity of centrosomes in Chinese hamster ovary cells is independent of the centriole cycle but coupled to the mitotic cycle. J. Cell Biol. 1981, 91, 822-826. [CrossRef]

197. Snyder, J.A.; McIntosh, J.R. Initiation and growth of microtubules from mitotic centers in lysed mammalian cells. J. Cell Biol. 1975, 67, 744-760. [CrossRef]

198. Palazzo, R.E.; Vogel, J.M.; Schnackenberg, B.J.; Hull, D.R.; Wu, X. Centrosome maturation. Curr. Top. Dev. Biol. 2000, 49, 449-470. [CrossRef]

199. Gasic, I.; Nerurkar, P.; Meraldi, P. Centrosome age regulates kinetochore-microtubule stability and biases chromosome mis-segregation. eLife 2015, 4. [CrossRef] [PubMed]

200. Dudka, D.; Meraldi, P. Symmetry Does not Come for Free: Cellular Mechanisms to Achieve a Symmetric Cell Division. Results Probl. Cell Differ. 2017, 61, 301-321. [CrossRef] [PubMed]

201. Pelletier, L.; Yamashita, Y.M. Centrosome asymmetry and inheritance during animal development. Curr. Opin. Cell Biol. 2012, 24, 541-546. [CrossRef] 
202. Manzano-Lopez, J.; Monje-Casas, F. Asymmetric cell division and replicative aging: A new perspective from the spindle poles. Curr. Genet. 2020. [CrossRef]

203. Yamashita, Y.M. The centrosome and asymmetric cell division. Prion 2009, 3, 84-88. [CrossRef]

204. Mazo, G.; Soplop, N.; Wang, W.J.; Uryu, K.; Tsou, M.F. Spatial Control of Primary Ciliogenesis by Subdistal Appendages Alters Sensation-Associated Properties of Cilia. Dev. Cell 2016, 39, 424-437. [CrossRef]

205. Hung, H.F.; Hehnly, H.; Doxsey, S. The Mother Centriole Appendage Protein Cenexin Modulates Lumen Formation through Spindle Orientation. Curr. Biol. 2016, 26, 793-801. [CrossRef]

206. Cajanek, L.; Nigg, E.A. Cep164 triggers ciliogenesis by recruiting Tau tubulin kinase 2 to the mother centriole. Proc. Natl. Acad. Sci. USA 2014, 111, E2841-E2850. [CrossRef]

207. Izawa, I.; Goto, H.; Kasahara, K.; Inagaki, M. Current topics of functional links between primary cilia and cell cycle. Cilia 2015, 4, 12. [CrossRef]

208. Wei, Q.; Xu, Q.; Zhang, Y.; Li, Y.; Zhang, Q.; Hu, Z.; Harris, P.C.; Torres, V.E.; Ling, K.; Hu, J. Transition fibre protein FBF1 is required for the ciliary entry of assembled intraflagellar transport complexes. Nat. Commun. 2013, 4, 2750. [CrossRef]

209. Huang, N.; Xia, Y.; Zhang, D.; Wang, S.; Bao, Y.; He, R.; Teng, J.; Chen, J. Hierarchical assembly of centriole subdistal appendages via centrosome binding proteins CCDC120 and CCDC68. Nat. Commun. 2017, 8, 15057. [CrossRef] [PubMed]

210. Yang, T.T.; Chong, W.M.; Wang, W.-J.; Mazo, G.; Tanos, B.; Chen, Z.; Tran, T.M.N.; Chen, Y.-D.; Weng, R.R.; Huang, C.-E.; et al. Super-resolution architecture of mammalian centriole distal appendages reveals distinct blade and matrix functional components. Nat. Commun. 2018, 9, 2023. [CrossRef] [PubMed]

211. Kashihara, H.; Chiba, S.; Kanno, S.I.; Suzuki, K.; Yano, T.; Tsukita, S. Cep128 associates with Odf2 to form the subdistal appendage of the centriole. Genes Cells Devoted Mol. Cell. Mech. 2019, 24, 231-243. [CrossRef]

212. Chong, W.M.; Wang, W.J.; Lo, C.H.; Chiu, T.Y.; Chang, T.J.; Liu, Y.P.; Tanos, B.; Mazo, G.; Tsou, M.B.; Jane, W.N.; et al. Super-resolution microscopy reveals coupling between mammalian centriole subdistal appendages and distal appendages. eLife 2020, 9. [CrossRef]

213. Viol, L.; Hata, S.; Pastor-Peidro, A.; Neuner, A.; Murke, F.; Wuchter, P.; Ho, A.D.; Giebel, B.; Pereira, G. Nek2 kinase displaces distal appendages from the mother centriole prior to mitosis. J. Cell Biol. 2020, 219. [CrossRef] [PubMed]

214. Guarguaglini, G.; Duncan, P.I.; Stierhof, Y.D.; Holmström, T.; Duensing, S.; Nigg, E.A. The Forkhead-associated Domain Protein Cep170 Interacts with Polo-like Kinase 1 and Serves as a Marker for Mature Centrioles. Mol. Biol. Cell 2005, 16, 1095-1107. [CrossRef]

215. Chen, C.-H.; Howng, S.-L.; Cheng, T.-S.; Chou, M.-H.; Huang, C.-Y.; Hong, Y.-R. Molecular characterization of human ninein protein: Two distinct subdomains required for centrosomal targeting and regulating signals in cell cycle. Biochem. Biophys. Res. Commun. 2003, 308, 975-983. [CrossRef]

216. Schmidt, K.N.; Kuhns, S.; Neuner, A.; Hub, B.; Zentgraf, H.; Pereira, G. Cep164 mediates vesicular docking to the mother centriole during early steps of ciliogenesis. J. Cell Biol. 2012, 199, 1083-1101. [CrossRef]

217. Anderson, C.T.; Stearns, T. Centriole Age Underlies Asynchronous Primary Cilium Growth in Mammalian Cells. Curr. Biol. 2009, 19, 1498-1502. [CrossRef]

218. Rapley, J.; Baxter, J.E.; Blot, J.; Wattam, S.L.; Casenghi, M.; Meraldi, P.; Nigg, E.A.; Fry, A.M. Coordinate regulation of the mother centriole component nlp by nek2 and plk1 protein kinases. Mol. Cell. Biol. 2005, 25, 1309-1324. [CrossRef]

219. Kong, D.; Farmer, V.; Shukla, A.; James, J.; Gruskin, R.; Kiriyama, S.; Loncarek, J. Centriole maturation requires regulated Plk1 activity during two consecutive cell cycles. J. Cell Biol. 2014, 206, 855-865. [CrossRef]

220. Novak, Z.A.; Wainman, A.; Gartenmann, L.; Raff, J.W. Cdk1 Phosphorylates Drosophila Sas-4 to Recruit Polo to Daughter Centrioles and Convert Them to Centrosomes. Dev. Cell 2016, 37, 545-557. [CrossRef]

221. Zou, C.; Li, J.; Bai, Y.; Gunning, W.T.; Wazer, D.E.; Band, V.; Gao, Q. Centrobin: A novel daughter centriole-associated protein that is required for centriole duplication. J. Cell Biol. 2005, 171, 437-445. [CrossRef]

222. Mahjoub, M.R.; Xie, Z.; Stearns, T. Cep120 is asymmetrically localized to the daughter centriole and is essential for centriole assembly. J. Cell Biol. 2010, 191, 331-346. [CrossRef]

223. Boutin, C.; Kodjabachian, L. Biology of multiciliated cells. Curr. Opin. Genet. Dev. 2019, 56, 1-7. [CrossRef]

224. Lewis, M.; Stracker, T.H. Transcriptional regulation of multiciliated cell differentiation. Semin. Cell Dev. Biol. 2020. [CrossRef] 
225. Al Jord, A.; Spassky, N.; Meunier, A. Motile ciliogenesis and the mitotic prism. Biol. Cell 2019, 111, $199-212$. [CrossRef]

226. Vladar, E.K.; Stearns, T. Molecular characterization of centriole assembly in ciliated epithelial cells. J. Cell Biol. 2007, 178, 31-42. [CrossRef]

227. Al Jord, A.; Shihavuddin, A.; Servignat d'Aout, R.; Faucourt, M.; Genovesio, A.; Karaiskou, A.; Sobczak-Thepot, J.; Spassky, N.; Meunier, A. Calibrated mitotic oscillator drives motile ciliogenesis. Science 2017, 358, 803-806. [CrossRef]

228. Revinski, D.R.; Zaragosi, L.E.; Boutin, C.; Ruiz-Garcia, S.; Deprez, M.; Thome, V.; Rosnet, O.; Gay, A.S.; Mercey, O.; Paquet, A.; et al. CDC20B is required for deuterosome-mediated centriole production in multiciliated cells. Nat. Commun. 2018, 9, 4668. [CrossRef]

229. Janke, C.; Bulinski, J.C. Post-translational regulation of the microtubule cytoskeleton: Mechanisms and functions. Nat. Rev. Mol. Cell Biol. 2011, 12, 773-786. [CrossRef]

230. Bobinnec, Y.; Moudjou, M.; Fouquet, J.P.; Desbruyeres, E.; Edde, B.; Bornens, M. Glutamylation of centriole and cytoplasmic tubulin in proliferating non-neuronal cells. Cell Motil. Cytoskelet. 1998, 39, $223-232$. [CrossRef]

231. Piperno, G.; LeDizet, M.; Chang, X.J. Microtubules containing acetylated alpha-tubulin in mammalian cells in culture. J. Cell Biol. 1987, 104, 289-302. [CrossRef]

232. LeDizet, M.; Piperno, G. Identification of an acetylation site of Chlamydomonas alpha-tubulin. Proc. Natl. Acad. Sci. USA 1987, 84, 5720-5724. [CrossRef]

233. Choudhary, C.; Kumar, C.; Gnad, F.; Nielsen, M.L.; Rehman, M.; Walther, T.C.; Olsen, J.V.; Mann, M. Lysine acetylation targets protein complexes and co-regulates major cellular functions. Science 2009, 325, 834-840. [CrossRef]

234. Chu, C.W.; Hou, F.; Zhang, J.; Phu, L.; Loktev, A.V.; Kirkpatrick, D.S.; Jackson, P.K.; Zhao, Y.; Zou, H. A novel acetylation of beta-tubulin by San modulates microtubule polymerization via down-regulating tubulin incorporation. Mol. Biol. Cell 2011, 22, 448-456. [CrossRef]

235. Wloga, D.; Joachimiak, E.; Fabczak, H. Tubulin Post-Translational Modifications and Microtubule Dynamics. Int. J. Mol. Sci. 2017, 18, 2207. [CrossRef]

236. Janke, C.; Magiera, M.M. The tubulin code and its role in controlling microtubule properties and functions. Nat. Rev. Mol. Cell Biol. 2020. [CrossRef]

237. Sahabandu, N.; Kong, D.; Magidson, V.; Nanjundappa, R.; Sullenberger, C.; Mahjoub, M.R.; Loncarek, J. Expansion microscopy for the analysis of centrioles and cilia. J. Microsc. 2019, 276, 145-159. [CrossRef]

238. Song, Y.; Brady, S.T. Post-translational modifications of tubulin: Pathways to functional diversity of microtubules. Trends Cell Biol. 2015, 25, 125-136. [CrossRef]

239. Yu, I.; Garnham, C.P.; Roll-Mecak, A. Writing and Reading the Tubulin Code. J. Biol. Chem. 2015, 290, 17163-17172. [CrossRef]

240. Bobinnec, Y.; Khodjakov, A.; Mir, L.M.; Rieder, C.L.; Edde, B.; Bornens, M. Centriole disassembly in vivo and its effect on centrosome structure and function in vertebrate cells. J. Cell Biol. 1998, 143, 1575-1589. [CrossRef]

241. Gambarotto, D.; Zwettler, F.U.; Le Guennec, M.; Schmidt-Cernohorska, M.; Fortun, D.; Borgers, S.; Heine, J.; Schloetel, J.G.; Reuss, M.; Unser, M.; et al. Imaging cellular ultrastructures using expansion microscopy (U-ExM). Nat. Methods 2019, 16, 71-74. [CrossRef]

242. Bettencourt-Dias, M.; Hildebrandt, F.; Pellman, D.; Woods, G.; Godinho, S.A. Centrosomes and cilia in human disease. Trends Genet. 2011, 27, 307-315. [CrossRef]

243. Brown, J.M.; Witman, G.B. Cilia and Diseases. Bioscience 2014, 64, 1126-1137. [CrossRef] [PubMed]

244. Nigg, E.A.; Raff, J.W. Centrioles, centrosomes, and cilia in health and disease. Cell 2009, 139, 663-678. [CrossRef]

245. Wang, L.; Dynlacht, B.D. The regulation of cilium assembly and disassembly in development and disease. Development 2018, 145. [CrossRef] [PubMed]

(C) 2020 by the authors. Licensee MDPI, Basel, Switzerland. This article is an open access article distributed under the terms and conditions of the Creative Commons Attribution (CC BY) license (http://creativecommons.org/licenses/by/4.0/). 